\section{ĶĪMIJAS SEKCIJA}

\section{Tēžu krājums}

\section{9. \\ 808}

Latvijas

Universitātes starptautiskā zinātniskā konference 
Latvijas Unlversitātes

79. starptautiskā zinātniskā konference

\section{ĶĪMIJAS SEKCIJA Tēžu krājums}

Book of Abstracts

The $79^{\text {th }}$ International Scientific Conference of the University of Latvia

CHEMISTRY SECTION 
Latvijas Universitātes 79. starptautiskā zinātniskā konference. Ķīmijas sekcija. Tēžu kräjums $=$ The $79^{\text {th }}$ International Scientific Conference of the University of Latvia. Chemistry Section. Book of Abstracts. Rīga: Latvijas Universitāte, 2021. 60 lpp.

Redkolēgija:

docents Artis Kinēns

asoc. prof. Agris Bērziņš

prof. Arturs Vīksna

Tēžu krājums publicēts autoru redakcijā

Maketētāja Andra Liepiņa

(C) Latvijas Universitāte, 2021

https://doi.org/10.22364/iscul.79.cs.ba

ISBN 978-9934-18-649-3 


\section{Saturs}

ANALĪTISKĀS KূīMIJAS SEKCIJA

M. Bertins, A. Brangule, A. Viksna. INTERFERENCE REMOVAL IN ICP-MS USING

HE COLLISION CELL WITH TANDEM MS

Z. Bērziṇa, R. Pavlıenko, M. Jansons. DETECTION OF PYRROLIZIDINE ALKALOIDS IN HERBAL TEAS OF LATVIAN ORIGIN USING NANO-FLOW CHROMATOGRAPHY - HIGH RESOLUTION MASS SPECTROMETRY

P. Blynskiy, Y. Chikhray, S. Askerbekov, I. Kenzhina, A. Shaimerdenov, Z. Zaurbekova. DEVELOPMENT OF THE EXPERIMENTAL TECHNIQUES FOR INVESTIGATION OF HIGH-TEMPERATURE CORROSION OF THE HTGR FUEL PROTOTYPES . .

D. Butkus, V. Rudoviča, O. Bikovens, M. Bērtinš̌. EVALUATION OF BEACH WRACK ALGAL BIOMASS CHEMICAL COMPOSITION ON KURZEME SHORE

D. Fedorenko, M. Jansons, V. Bartkevičs. APPLICATION OF NANOFLOW LIQUID CHROMATOGRAPHY FOR IMPROVEMENTS OF MASS SPECTROMETRIC DETECTION SENSITIVITY

D. Godina, K. Meile, A. Viksna, A. Zhurinsh. APPLICATIONS OF BIO-CHAR AS A CATALYST

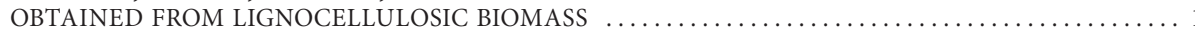

V. Grebnevs, A. Vīksna, K.-A. Gross. COMPREHENSIVE PHYSICOCHEMICAL

CHARACTERIZATION OF VARIOUS CALCIUM PHOSPHATES - PROBLEMS, TRENDS AND PERSPECTIVES

V. Grebnevs, K. Leśniak-Ziółkowska, M. Wala, R. Viter, A. Vīksna, W. Simka. A PRELIMINARY STUDY ON PREPARATION OF BIOACTIVE CALCIUM PHOSPHATE INCORPORATED OXIDE COATINGS ON TITANIUM SUBSTRATES BY PLASMA ELECTROLYTIC OXIDATION $\ldots \ldots \ldots \ldots \ldots 13$ L. E. Ikkere, I. Pugajeva. DETERMINATION OF 5-HYDROXYINDOLEACETIC ACID IN WASTEWATER SAMPLES FROM WASTEWATER TREATMENT PLANTS IN LATVIA

I. Kenzhina, S. Askerbekov, Y. Ponkratov, Y. Gordienko, I. Tazhibayeva, K. Kadyrzhanov, Y. Chikhray. EXPERIMENTS ON LITHIUM CPS IRRADIATION AT THE IVG1.M RESEARCH REACTOR .

K. D. Labsvārds, L. Buša, J. Ruško, R. Klūga, M. Bērtiňš, J. Naumenko, V. Rudoviča, M. Šalajeva, A. Vìksna. APPLICATION OF CHEMOMETRIC METHODS FOR ASSESMENT OF MONOFLORAL AND POLYFLORAL HONEY

V. Lazarenko, Y. Rublova, R. Meija, J. Andžāne, V. Voikiva, E. Kauranens, A. Vīksna, D. Erts. ELECTROCHEMICAL PROCESS IN SINGLE-WALLED CARBON NANOTUBES (SWCNT) FROM AQUEOUS SOLUTION

K. Lovcova, M. Bertins, D. Lazdina, S. Zake, A. Viksna. IMPACT OF SEWAGE SLUDGE ON

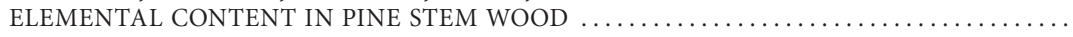

M. Mežulis, L. Kḷaviňš, I. Pērkons, V. Bartkevičs, A. Viksna, M. Kḷaviṇš. SEPERATION OF CRANBERRY PROCYANIDINS USING BIOLOGICAL ACTIVITY GỦIDED FRACTIONATION

M. Neimane, V. Lazarenko, M. Bērtinšs, A. Vīksna, D. Lazdina, K. Makovskis, I. Kārklina, A. Lazdiňš. EVALUATION OF THE CHEMICAL COMPOSITION OF MACRO- AND MICROELEMENTS IN THE BOTTOM AND FLY WOOD ASH

M. Pāls, A. Aršanica, A. Viksna. METHODS FOR SEPARATION OF LIPOPHILIC COMPOUNDS TO PURIFY ORGANOSOLV LIGNIN ISOLATED FROM ASPEN BARK. $\ldots \ldots \ldots \ldots \ldots \ldots \ldots \ldots \ldots \ldots 21$

E. Pasecnaja, D. Zacs. CONTAMINATION OF FOODSTUFFS WITH PER- AND POLIFLUORALKYL

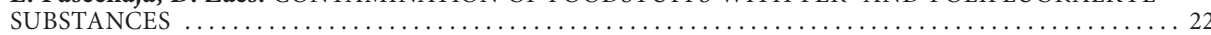

R. Pavlenko, Z. Bērziṇa, E. Bogdanova, M. Jansons, V. Bartkevičs. OPTIMISATION OF THE SAMPLE PREPARATION STRATEGY FOR THE ANALYSIS OF MYCOTOXINS IN WASTEWATER SAMPLES

D. Riekstina, M. Plūme, V. Gostilo, G. Kizāne. STUDIES ON THE COMPLIANCE OF WOODCHIP ASH WITH RADIATION SAFETY STANDARDS

K. Saleniece, U. Eismonts, M. Bertins, O. Muter, S. Gaidukovs, A. Vīksna, Z. Balcerbule, G. Kizane, I. Reinholds, A. Grinbergs. SYNTHESIS AND APPLICATION OF FERROCYANIDES FOR EFFICIENT ADSORPTION OF CAESIUM ON CELLULOSE AND ITS DERIVATIVES $\ldots \ldots \ldots \ldots 25$

I. Shtangeeva, A. Viksna, M. Bertins. SHORT TERM VARIATIONS IN ELEMENT CONCENTRATIONS IN THE RHIZOSPHERE SOIL OF COUCH GRASS (ELYMUS REPENS) AND

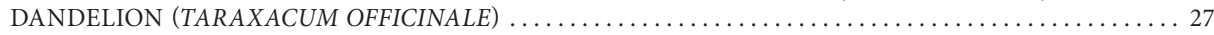

D. Übele, I. Šteins, D. Valdniece, A. A. Pudule, K. A. Gross. STORED CHARGE DETERMINATION OF SPARK PLASMA SINTERED AMORPHOUS CALCIUM PHOSPHATE . . . . . 29

K. Upska, L. Klavins, V. Nikolajeva, L. Faven, E. Isosaari, A. Viksna, M. Klavins. EXTRACTION AND CHARACTERISATION OF WILD AND CULTIVATED INONOTUS OBLIQUUS TRITERPENOID AND ELEMENTAL PROFILES

S. Zake, M. Bertins, D. Lazdina, K. Dumins, A. Viksna. APPLICATION OF $\triangle 15 \mathrm{~N}$ VALUES

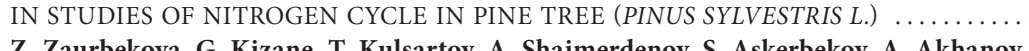
Y. Chikhray. PRELIMINARY EXPERIMENTS FOR STUDYING OF LITHIUM CERAMICS INTERACTION WITH NEUTRON IRRADIATION USING VACUUM EXTRACTION METHOD 
A. Ansone, A. Zarinš, L. Avotina, G. Kizāne. ANALYSIS OF SORBED GASES ON SURFACE OF LITHIUM ORTHOSILICATE BASED CERAMICS WITH THERMOGRAVIMETRY AND IR SPECTROMETRY

A. Auce, I. Auce, I. Horns, A. Jeremuss, S. Ivanovs, M. Drozdovs, Ā. Rucinš. REDUCTION OF $\mathrm{CO}_{2}$ EMISSIONS IN GREENHOUSE HEATING BY USING AIR TO AIR HEAT PUMP $\ldots \ldots \ldots \ldots \ldots . \ldots 35$ L. Avotina, E. Pajuste, I. Reinholds, E. Sprūǵis, G. Vaivars. ANALYSIS OF ELECTRON IRRADIATED PROTON EXCHANGE MEMBRANES WITH INFRARED SPECTROMETRY $\ldots \ldots \ldots . \ldots 36$ R. Bobrovs, I. Kanepe-Lapsa, K. Jaudzems. IDENTIFICATION OF POTENTIAL PLASMEPSIN IX INHIBITORS USING HIGH-THROUGHPUT VIRTUAL SCREENING $\ldots \ldots \ldots \ldots \ldots \ldots \ldots \ldots \ldots \ldots . \ldots \ldots$ L. Bugovecka, K. Buks, K. Niherush, J. Andžāne, D. Erts. SYNTHESIS AND PROPERTIES OF FLEXIBLE CARBON NANOTUBE-METAL CHALCOGENIDE STRUCTURES $\ldots \ldots \ldots \ldots \ldots \ldots \ldots . \ldots 38$ Z. Čerpakovska, K. Saršūns, A. Bērziņš. INVESTIGATION OF POSSIBILITIES TO CONTROL THE POLYMORPH OBTAINED IN CRYSTALLIZATION OF 3-HYDROXYBENZOIC ACID $\ldots \ldots \ldots 39$

S. Homiča, E. Sprūğis, G. Vaivars. PREPARATION OF ZIRCONIUM DIOXIDE NANODISPERSIONS FROM ZIRCONIUM OXYCHLORIDE OKTAHYDRATE AND ELECTRICAL PROPERTIES OF PREPARED DISPERSIONS

L. Jasulaneca, R. Meija, E. Kauranens, R. Sondors, J. Andzane, J. Prikulis, G. Kunakova, D. Erts. FABRICATION AND CHARACTERIZATION OF ON-CHIP SEMICONDUCTOR NANOWIRE NANOELECTROMECHANICAL SWITCHES

P. Kalnina, E. Pajuste, G. Kizane. OPTIMIZATION OF THE EFFICIENCY OF THE DISTILLATION METHOD FOR THE SEPARATION OF TRITIUM FROM BERYLLIUM-CONTAINING ACID SOLUTIONS

K. Kokina, V. Valkovska. CHEMICAL COMPOSITION OF MALUS DOMESTICA LEAVES ........ 43

A. Kons, A. Mishnev, T. A. Mukhametzyanov, A. V. Buzyurov, S. E. Lapuk, A. Bērzinšs. HEXAMORPHISM OF DANTROLENE: INSIGHT INTO THE CRYSTAL STRUCTURES, STABILITY, AND PHASE TRANSFORMATIONS

E. Lagzdina, E. Pajuste, G. Kizane, A. Lescinskis. INCONEL-718 ALLOY

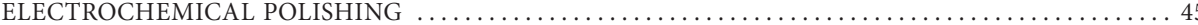

K. Saršūns, A. Karzininins, K. Leduskrasts, A. Bērzinšs, T. Rekis. FORMATION OF SOLID SOLUTION IN XANTHONE DERIVATIVE SYSTEMS̉ EXHIBITING LUMINESCENCE PROPERTIES . . 46 A. Semjonova, A. Bērziñš. SCREENING OF CRYSTALLIZATION ADDITIVES FOR POLYMORPH

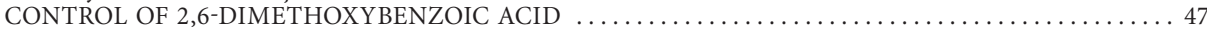

T. E. Šusts, E. Pajuste, G. Kizāne. EFFECTS OF RADIATION ON CMS MTD BTL COMPONENTS AND BINDING MATERIALS

A. Trimdale, A. Bērziṇš. BEHAVIOR OF DIHYDROXYBENZOIC ACID MOLECULES IN SOLUTIONS DETERMINED USING SPECTROSCOPIC METHODS AND MOLECULAR DYNAMICS SIMULATIONS, AND THE POSIIBLE EFFECT OF DISPARITIES ON THEIR PROPENSITY TO FORM SOLID PHASES

A. Trubača-Boginska, R. Ādina, A. Prikšāne, G. Vaivars, J. Švirksts. MODIFICATION OF BENTONITE CLAY WITH ZWITTERIONS FOR APPLICATION IN SPEEK COMPOSITE MEMBRANES ...

V. Valkovska, L. Orola. CHARACTERIZATION OF PIGMENTS FROM RUMEX CONFERTUS

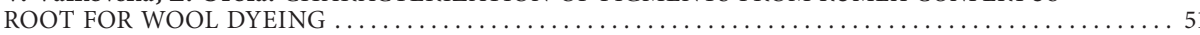

ORGANISKĀS K̦ĪMIJAS SEKCIJA

L. L. Barbare. TOWARDS DYNAMIC KINETIC RESOLUTION OF AMINES $\ldots \ldots \ldots \ldots \ldots \ldots \ldots \ldots 5$

A. Burcevs, A. Sebris, A. Jeminejs. SYNTHESIS AND PHOTOPHYSICAL PROPERTIES OF

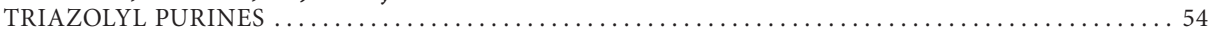

A. Čižikovs. COBALT-CATALYZED C(sp $\left.{ }^{2}\right)$-H BOND CARBONYLATION $\ldots \ldots \ldots \ldots \ldots \ldots \ldots \ldots \ldots$

A. R. Feldmanis, O. Filipsons. A MECHANISTICAL STUDY OF LEWIS BASE CATALYZED

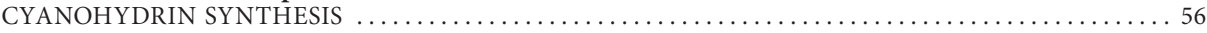

A. Jeminejs. SYNTHESIS OF TETRAZOLO $[1,5-\mathrm{C}]$ QUINAZOLINE DERIVATIVES $\ldots \ldots \ldots \ldots \ldots \ldots . \ldots 7$

G. Jersovs. SYNTHETIC APPROACH TO SULPHUR BASED ENANTIOPURE $\Gamma$-LACTAM

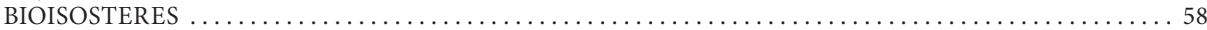

S. Kaštaljana. SYNTHESIS OF LINKERS FOR BIOCONJUGATION OF SARS-COV-2 RECEPTOR-BINDING DOMAIN SPIKE PROTEIN WITH Q $\beta$ VLPs $\ldots \ldots \ldots \ldots \ldots \ldots \ldots \ldots \ldots \ldots . \ldots . \ldots . \ldots$

V. Kovada. SYNTHESIS OF NOVEL ASPARTIC-PROTEASE INHIBITORS FOR TREATMENT OF MALARIA

A. Sebris. SYNTHESIS AND PHOTOPHYSICAL PROPERTIES OF STERICALLY HINDERED

D. Sloboda, D. Hazens, I. Kḷimenkovs. SYNTHESIS AND PROPERTIES OF ISOELECTRONIC

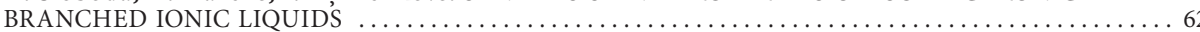

A. Sperga. SYNTHESIS OF FLUORINATED ISOXAZOLINE $N$-OXIDES THROUGH FLOUROMETHYLENE TRANSFER 


\section{Analītiskās \\ ķīmijas sekcija}




\title{
INTERFERENCE REMOVAL IN ICP-MS USING HE COLLISION CELL WITH TANDEM MS
}

\author{
Maris Bertins ${ }^{1}$, Agnese Brangule ${ }^{2}$, Arturs Viksna ${ }^{1}$ \\ ${ }^{1}$ University of Latvia, Faculty of Chemistry, Jelgavas iela 1, Riga, Latvia \\ ${ }^{2}$ Riga Stradiňš University, Riga, Latvia \\ e-mail: Maris.Bertins@lu.lv
}

Inductively coupled plasma mass spectrometry (ICP-MS) is a very powerful multi-element analysis technique, but it suffers from some spectral interferences, which are very well-documented, and it can be very problematic when some difficult, complex, and variable samples of different origin are analyzed. Interferences in ICP-MS mainly are caused due to a polyatomic (or molecular) ion at the same $\mathrm{m} / \mathrm{z}$ ratio as the analyte of interest.

Nowadays ICP-MS is not imaginable without collision/reaction cell and is a standard analytical technique for measurement of a wide range of elements in different kind and origin of environmental (water, soil, plants, etc.) as well as pharmaceutical and other samples. But nevertheless, some spectral interferences still create problems for the determination of several elements. Dilution or use of some other isotope with less natural occurrence can minimize these interferences, but some industries (semiconductor, pharmacology) require low detection limits in complex chemicals with high purity.

Some devices like Agilent 8900 ICP-QQQ features tandem MS configuration, which consists of a scanning quadrupole mass analyzer on either side of an octopole-based collision/reaction cell (CRC). This configuration enables to use of ICPMS in MS/MS mode in which it is possible to resolve difficult spectral interferences in a wide range of sample types using reactive cell gases. MS/MS mode also can be used for the more difficult elements and problematic interferences that can be encountered in routine analysis, for example, food, sludge, soil, and wastewater.

The main aim of this study was to evaluate the possibilities of simple He collision cell together with tandem MS/MS system to minimize impact from polyatomic interferences.

In this study, four SRM's were analyzed (Lichen (IAEA 336), Algae (IAEA 392), Algae (IAEA 413), and White Cabbage (BCR 679). Measurements were done with Agilent 8900 ICP-MS QQQ) equipped with a micro-mist nebulizer and He collision cell (He gas flow $5.0 \mathrm{~mL} \mathrm{~min}{ }^{-1}$ ). Measurements were done in both single MS and tandem MS/MS regimes.

Results of this study showed that it is possible to make ${ }^{28} \mathrm{Si}$ measurements using ICPMS together with He collision cell with tandem MS/MS system while it is impossible to measure silica in a single MS system due to high interference from atmospheric nitrogen $\left(\mathrm{N}_{2}, \mathrm{~m} / \mathrm{z}=28\right)$. Better results are also obtained for measurements for ${ }^{39} \mathrm{~K}$, where some imprecision of measurements can be due to ${ }^{38} \mathrm{Ar}^{1} \mathrm{H}$ $(\mathrm{m} / \mathrm{z}=39)$ interferences in a single MS system. 


\section{DETECTION OF PYRROLIZIDINE ALKALOIDS IN HERBAL TEAS OF LATVIAN ORIGIN USING NANO-FLOW CHROMATOGRAPHY - HIGH RESOLUTION MASS SPECTROMETRY}

\section{Zane Bērziṇa ${ }^{1,2}$, Romans Pavḷenko ${ }^{1,2}$, Mārtiṇš Jansons ${ }^{1}$}

${ }^{1}$ Institute of Food Safety, Animal Health and Environment "BIOR”, Lejupes iela 3, Riga LV-1076, Latvia

${ }^{2}$ Faculty of Chemistry, University of Latvia, Jelgavas iela 1, Riga LV-1004, Latvia e-mail:zane.berzina@bior.lv

Pyrrolizidine alkaloids (PA) are one of the groups of plant-synthesized alkaloids that a plant accumulates in its body to prevent exposure to insects and animals. It is estimated that $3 \%$ of the world's flowers synthesize these compounds and, although they have different properties, many of them are classified as cytotoxic, hepatoxic, genotoxic and their presence in food may pose both acute and chronic exposure risks to the consumer [1].

The tea matrix is complex and the expected PA concentrations are low, therefore a selective and sensitive method using QuEChERS extraction and nano-flow LC/MS was developed. In total 15 herbal teas were analyzed where $47 \%$ of samples had PA concentrations above the LOQ 1.Fig.

The PA was determined in teas prepared according to the instructions on the package to assess the transfer of the determined PA concentration to the drinking solution. While tea is prepared, it extracts from $1.15 \%$ to $64 \%$ PA, depending on the compound and the type of tea.

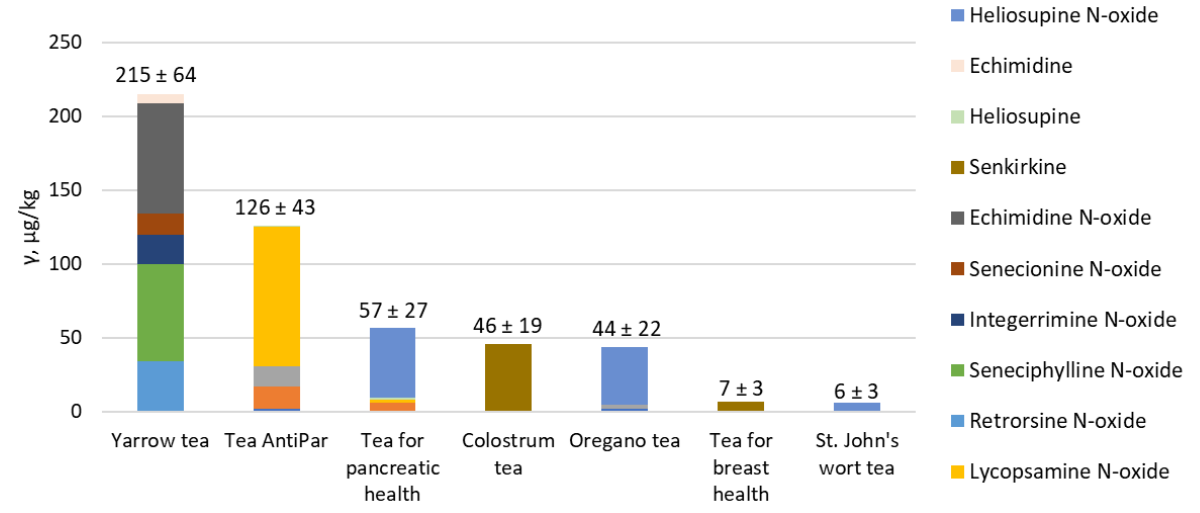

Fig. 1. Concentration of PA in different herbal teas of Latvian origin

The obtained results show that the highest content of PA is found in teas containing yarrow leaves. The data obtained on PA contamination in tea and its extraction in water during tea production can be used for risk assessment.

\section{References:}

[1] Moreira, R.; Pereira, D. M.; Valentão, P.; Andrade, P. B. Pyrrolizidine Alkaloids: Chemistry,

Pharmacology, Toxicology and Food Safety. Int. J. Mol. Sci. 2018, 19 (6)1668. 


\title{
DEVELOPMENT OF THE EXPERIMENTAL TECHNIQUES FOR INVESTIGATION OF HIGH-TEMPERATURE CORROSION OF THE HTGR FUEL PROTOTYPES
}

\author{
Petr Blynskiy ${ }^{1}$, Yevgen Chikhray ${ }^{1 *}$, Saulet Askerbekov ${ }^{1,2}$, \\ Inesh Kenzhina ${ }^{1}$, Asset Shaimerdenov ${ }^{1,3}$, Zhanna Zaurbekova ${ }^{1}$ \\ ${ }^{1}$ Al-Farabi Kazakh National University, 71, al-Farabi ave, Almaty, Kazakhstan \\ ${ }^{2}$ L.N. Gumilyov Eurasian National University, 2, Satpayev str., Astana, Kazakhstan \\ ${ }^{3}$ Institute of Nuclear Physics, 1, Ibragimov str., Almaty, Kazakhstan \\ e-mail:chikhray@physics.kz
}

Application of composite materials (such as SiC-coatings, TRISO-type coating) as corrosion-resistive coating over graphites remains important task for HTGR for years. Different methods and technologies were developed for composite coatings over fuel and graphite frames to reduce theirs chemical corrosion/spraying and sorption capacity with respect to hydrogen. The use of such coating would lead to some stabilization of the structure of carbon formations and their properties, which are changing in almost all HTGR operational regimes.

In this work the study of chemical interaction of the $\mathrm{SiC}$ gradient coating over the high-density graphite with $\mathrm{H}_{2} \mathrm{O}, \mathrm{O}_{2}, \mathrm{CH}_{4}, \mathrm{H}_{2}$, at pressures 1 and $100 \mathrm{~Pa}$ in the temperature range up to $1573 \mathrm{~K}$ is presented. The experiments were carried out using mass spectrometric registration of time dependencies of partial pressures change of the gas mixture at a constant temperature of the sample (integral mode).

The experimental results and microstructural study enable to obtain parameters and peculiarities of the material's corrosin and come to conclusions on the level of the reduction of gases interaction with the bulk graphite due to SiC-coating.

The work is supported by the Ministry of Education and Science of the Republic of Kazakhstan with Grant No. AP08052726. 


\title{
EVALUATION OF BEACH WRACK ALGAL BIOMASS CHEMICAL COMPOSITION ON KURZEME SHORE
}

\author{
Džesika Butkus ${ }^{1,2}$, Vita Rudoviča', Oskars Bikovens' ${ }^{2}$, Māris Bērtiṇš ${ }^{1}$ \\ ${ }^{1}$ University of Latvia, Faculty of Chemistry, Jelgavas street 1, Riga, Latvia \\ ${ }^{2}$ Latvian State Institute of Wood Chemistry, Dzerbenes street 27, Riga, Latvia \\ e-mail:db12151@lu.lv
}

The total length of the Latvian coast exceeds $500 \mathrm{~km}$. Every year, a large amount of seaweed is washed to the coast forming beach wrack. Algae have a wide range of applications, they are used in pharmacy, industry, food, agriculture, cosmetics [1].

Due to the large inflow of fresh water from rivers and precipitation, anthropogenic water pollution in the Baltic Sea is increasing. Algae, like other marine organisms, have the ability to accumulate various harmful substances [2].

The chemical composition of algal biomass depends on many factors, such as species, location and water pollution levels. In order to optimally master the available resources in the territory of Latvia, the chemical and botanical composition of seaweed on the coast of Kurzeme was evaluated.

The algal biomass washed up on the beaches of Liepāja and Pāvilosta is mainly dominated by such algae species as: red algae furcellaria (Furcellaria lumbricalis) and brown algae bladder fuchsia (Fucus vesiculosus). Red algae coccotylus (Coccotylus truncata) and other algae were also washed out in relatively small quantities, mainly annual kelp and red algae.

Using ICP-MS spectrometric analysis method, the content of 40 chemical elements was determined in seaweed, 11 of which were elements of the lanthanide group, the concentration of which varied from $3.7 \mu \mathrm{g} \cdot \mathrm{kg}^{-1}$ (Ho) to $5624 \mu \mathrm{g} \cdot \mathrm{kg}^{-1}(\mathrm{Ce})$. The concentration of heavy metals in algae varies greatly $\left(0.0052-705 \mathrm{mg} \cdot \mathrm{kg}^{-1}\right)$. The concentration of $\mathrm{Zn}$ varies from 43.2 to $705 \mathrm{mg} \cdot \mathrm{kg}^{-1}, \mathrm{Cu}-1.65-32.2 \mathrm{mg} \cdot \mathrm{kg}^{-1}$, $\mathrm{Ni}-3.8-10.5 \mathrm{mg} \cdot \mathrm{kg}^{-1}, \mathrm{Cd}-0.059-0.67 \mathrm{mg} \cdot \mathrm{kg}^{-1}$ and $\mathrm{Hg} 0.0052-0.022 \mathrm{mg} \cdot \mathrm{kg}^{-1}$ in algae. The species of algae and the sampling location largely determine the content of chemical elements.

Different species of algae may accumulate metals and metalloid compounds in various ways. The composition of chemical elements in the algal biomass washed out on the beaches of Liepāja and Pāvilosta is in most cases similar, however, the content of individual elements may differ two or more times, for example, chromium (Cr), cobalt (Co), arsenic (As), rubidium (Rb) content in red algae collected on the Liepāja coast larger than in Pāvilosta. They may indicate possible anthropogenic pollution.

\section{References:}

[1] B. Chubarenko, J. et.al. Converting beach wrack into a resource as a challenge for the Baltic Sea (an overview), Ocean \& Coastal Management, 2020, 105413, ISSN 0964-5691.

[2] Bikovens, O. (2019) Alğ́u biomasas izmantošanas iespēju analizze Rīgas plānošanas reǵiona piekrastē. Pètijuma Nr.RPR/2018/5/SBR Gala ziṇojums. Rīga.

Acknowledgment: This research was financially supported by Kurzeme planning region, INTERREG project Growing Algae Sustainably in the Baltic Sea (GRASS). 


\title{
APPLICATION OF NANOFLOW LIQUID CHROMATOGRAPHY FOR IMPROVEMENTS OF MASS SPECTROMETRIC DETECTION SENSITIVITY
}

\author{
Deniss Fedorenko', 2, Mārtiṇš Jansons ${ }^{2}$, Vadims Bartkevičs ${ }^{1,2}$ \\ ${ }^{1}$ University of Latvia, Faculty of Chemistry, Jelgavas iela 1, Riga, Latvia \\ 2 Institute of Food Safety, Animal Health and Environment "BIOR", Lejupes iela 3, Riga, Latvia \\ e-mail:deniss.fedorenko@bior.lv
}

The rapid development of separation science, miniaturization and automation of liquid chromatography systems has resulted in the availability of advanced liquid chromatography equipment, such as nanoflow liquid chromatography (nano-LC). Due to the reduced flow rates, consumption of solvents is decreased. Advantages of this type of liquid chromatography include reduced chromatographic dilution, higher mass sensitivity, and lower injection volume [1].

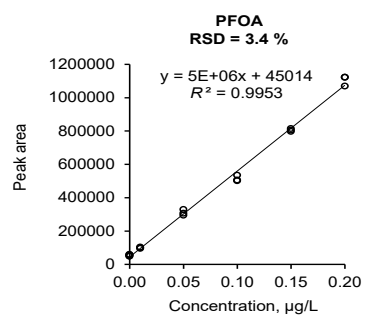

Fig. 1. Perfluorooctanoic acid calibration. Replicates analysed in 6 hours with nano-LC-MS.

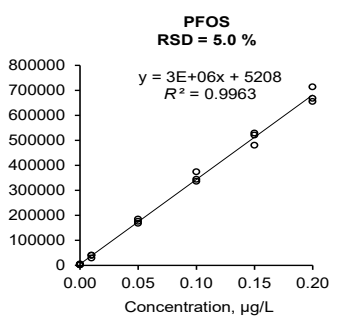

Fig. 2. Perfluorooctanesulfonic acid calibration.

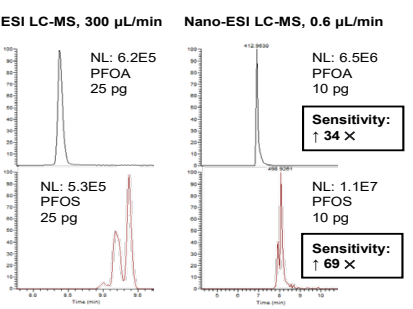

Fig. 3. Improvement in PFASs sensitivity with nano-ESI LCMS compared to LC-MS.

Nowadays, nano-LC methods have a considerable range of applications, including proteomics, food safety applications and environmental sample analysis $[1,2]$. We have conducted experiments to explore the applicability of nano-LC-MS for increasing mass spectrometric detection sensitivity.

In our experiments steel and silica emitters were used. It is preferred to use integrated emitter column for best resolution, however, a gradient from fully aqueous to organic mobile phase, can show electrospray instability. Various instrumental setups, as well as post-column solvent addition for electrospray stabilization were implemented. A strong relationship between dilution factor and matrix effects exists and implementing dilution can result in better stability and lower matrix effects. Obtained empirical results were applied to the analysis of perfluorooctanoic and perfluorooctanesulfonic acid, and considerable improvements in sensitivity were observed in comparison with conventional LC-MS.

The preliminary results demonstrated that the advantage of nano-LC-MS over conventional LC-MS is not uniform across different applications, and therefore the further experimental assessment needs to be carried out.

Acknowledgement: Project No. lzp-2020/2-0128 funded by the Latvian Council of Science.

\section{References:}

[1] Fanali S. Electrophoresis 2017, 38, 1822-1829.

[2] Gama M. R., Collins C. H., Bottoli C. B. G. J. Chromatogr. Sci., 2013, 51, 694-703. 


\title{
APPLICATIONS OF BIO-CHAR AS A CATALYST OBTAINED FROM LIGNOCELLULOSIC BIOMASS
}

\author{
Daniela Godina ${ }^{1}, 2^{\star}$, Kristine Meile ${ }^{1}$, Arturs Viksna ${ }^{2}$, Aivars Zhurinsh ${ }^{1}$ \\ ${ }^{1}$ Latvian State Institute of Wood Chemistry, Dzerbenes 27, LV-1006 Riga, Latvia \\ ${ }^{2}$ University of Latvia, Jelgavas 1, LV-1004 Riga, Latvia \\ e-mail:danielagodina393@gmail.com
}

In the biomass fast pyrolysis process the solid residue - bio-char is obtained as a by-product. The bio-char can be used in different applications, such as the production of activated carbon. Activated carbons are carbonaceous materials with a highly developed internal surface area and porosity and are widely used as catalysts. It is important to note that activated carbon when used as a catalyst can be easily removed from the reaction mixture, washed, and activated again. In comparison with sulfuric acid, it cannot be done. The activation methods can be divided into 2 groups: physical activation and chemical activation.

In this work we used different bio-chars, that were obtained in biomass carbonization or pyrolysis process (Figure 1.). As activation methods we used chemical activation by sulfonation or physical activation with water steam.

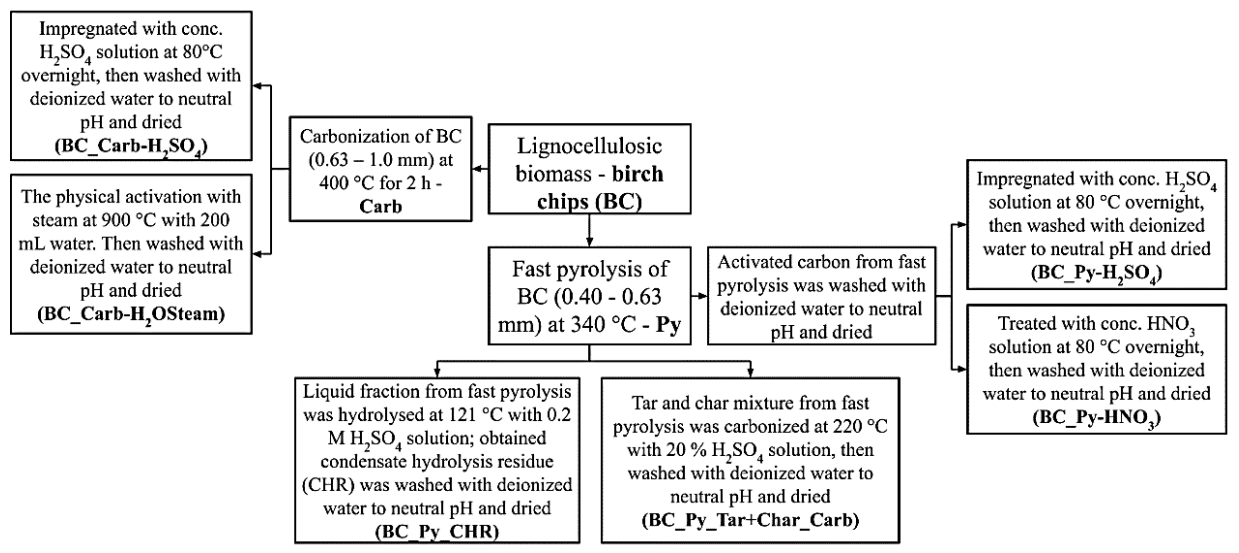

Fig. 1. Catalyst generation scheme

For the determination of the catalytic activity, the cellobiose (CB) hydrolysis was performed as a model reaction. Firstly, the experiments to determine $\mathrm{CB}$ hydrolysis reaction kinetics and the optimal conditions (temperature, time and catalyst: $\mathrm{CB}$ mass ratio) were done with biochar $\mathrm{Py}-\mathrm{H}_{2} \mathrm{SO}_{4}$ under pressurised conditions.

For the determination of the catalytic activity also acetic acid esterification with ethanol was used as a model reaction. The relative percentage of acetic acid during the reaction was determined by titration with $\mathrm{KOH}$ solution.

Qualitative and quantitative measurements of cellobiose, glucose and degradation products were done using a UHPLC system. CB and glucose analysis were done with evaporative light scattering detector (ELSD) using a BEH amide column. Carbohydrate degradation product concentration was determined with diode array detector (DAD) using CSH Phenyl-Hexyl column. 


\title{
COMPREHENSIVE PHYSICOCHEMICAL CHARACTERIZATION OF VARIOUS CALCIUM PHOSPHATES - PROBLEMS, TRENDS AND PERSPECTIVES
}

\author{
Vladlens Grebṇevs' ${ }^{1}$, Arturs Vīksna' ${ }^{1}$ Kārlis-Agris Gross² \\ ${ }^{1}$ University of Latvia, Faculty of Chemistry, Jelgavas street 1, Riga, Latvia \\ ${ }^{2}$ Biomaterials Research Laboratory, Riga Technical University, Paula Valdena street 3/7, \\ Riga, Latvia \\ e-mail: vladlens.grebnevs@lu.lv
}

Calcium phosphates and those containing materials can be considered as one of the broader fields of modern scientific research by many objective reasons. In literature calcium phosphates were first mentioned in 1770, describing attempts to determine the chemical composition of various animal bones. Since then, a number of important discoveries have been made that facilitated the wide spreading of calcium phosphates among different spheres of human activity finding applications in food industry, constructing, agriculture, ceramics, pharmaceuticals, etc. Over the last 80 years the demand for calcium phosphates especially has increased in biomedicine and implantology, which is related to the rapid ageing of population, sedentary lifestyle, urbanization and deterioration of the ecological situation in big cities. Factors mentioned determine the need for in-depth experimental research to create innovative solutions aimed at improving the quality of implants, achieving ever-increasing biocompatibility and higher identity of chemical composition and physical properties of those to natural bone.

Developing new implant technologies or improving existing ones, there is a demand for more precise, accurate and simpler analysis methods, which would ensure the strict control of all production process stages starting from raw material purity testing and finishing by evaluation of product quality before sale. Despite the fact that the range of known physicochemical methods is quite wide and their potential for achieving the highlighted tasks can be assessed as high, there are still numerous unsolved problems in the comprehensive characterization of calcium phosphates, which noticeably limit further development implantology and hinder scientific progress in general. The problems mainly concern issues related to chemical analysis, such as the rapid and simultaneous quantification of different elements and / or ions [1]. The most pressing and complex problems are connected with calcium, phosphorus, carbonate and hydroxyl ions as the four main components of the bone neogranite fraction.

The aim of the report is to provide a comparative insight into calcium phosphate and those containing biomaterial physicochemical characterization methods, taking into account the latest scientific trends, as well as to show the diversity of parameters to be determined and emphasize the need for each analysis. As a practical example, a variant of the multi-stage production cycle of calcium phosphate coating is demonstrated, including the synthesis procedure, post-treatment of the synthesized product and its further application onto metallic substrate surface using plasma electrolytic oxidation technique. Based on the available information on the research made during recent decades, short-term perspectives for development of calcium phosphate field are outlined.

\section{References:}

[1] Grebnevs, V., Busa, L., Pluduma, L., Gross, K. G., Viksna, A. Comparison of Different Classical and Instrumental Analysis Methods for Precise Quantification of Calcium and Phosphorous Ratio in Hydroxyapatite. Key Engineering Materials, 2019, 800, 47-51. 


\title{
A PRELIMINARY STUDY ON PREPARATION OF BIOACTIVE CALCIUM PHOSPHATE INCORPORATED OXIDE COATINGS ON TITANIUM SUBSTRATES BY PLASMA ELECTROLYTIC OXIDATION
}

\author{
Vladlens Grebṇevs', Katarzyna Leśniak-Ziółkowska², Marta Wala², \\ Roman Viter ${ }^{3}$, Arturs Vīksna', Wojciech Simka² \\ ${ }^{1}$ University of Latvia, Faculty of Chemistry, Jelgavas street 1, Riga, Latvia \\ 2 Silesian University of Technology, Faculty of Chemistry, B. Krzywoustego str. 6, Gliwice, \\ Poland \\ ${ }^{3}$ University of Latvia, Institute of Atomic Physics and Spectroscopy, Jelgavas street 3, Riga, \\ Latvia \\ e-mail:vladlens.grebnevs@lu.lv
}

Calcium phosphates are the most commonly used materials for modification of bone and dental implant surface due to their high chemical similarity to the inorganic fraction of human hard tissues. Presence of calcium phosphates onto the surface of implants makes them biocompatible and bioactive, which promotes good osteointegration and osteoconductivity in vivo.

Nowadays plasma electrolytic oxidation (PEO) is gaining more popularity due to the relative simplicity and rapidity of the procedure and, what is more important, the possibility to obtain porous, up to $500 \mu \mathrm{m}$ thick mechanically-resistant oxide layers. The method is similar to anodizing, but differs in the use of higher voltages usually exceeding $100 \mathrm{~V}$ and more.

There are several approaches of calcium phosphate incorporation into the oxide layer during the PEO process. The most commonly used is synthesis directly in the reaction cell by adding different salt solutions to the electrolyte [1], however, in this way it is hard to achieve desired coating elemental and phase composition as well as to eliminate surface porosity, which is an obligatory condition for the longterm wear resistance of the material. A modern approach is to add calcium phosphate suspension to the electrolytic solution. As a result, pre-synthesized particles of a certain size are incorporated into the surface structure by partial melting, not only covering the pores (Fig. 1-a, b), but also ensuring wider range of possible surface phase compositions.

The aim of current study is to evaluate the factors potentially influencing the properties of PEO surfaces - metallic substrate composition, electrolyte properties, calcium phosphate particle shape, size, concentration and stoichiometry. It has been found that electrolyte $\mathrm{pH}$ and carbonate content in particles have an effect on surface wettability, while particle size influence on its roughness and morphology. Particle incorporation was proved by Raman spectroscopy and EDX analysis. Bioactivity was assessed by observing apatite crystal growth after SBF tests (Fig. 1-c, d).
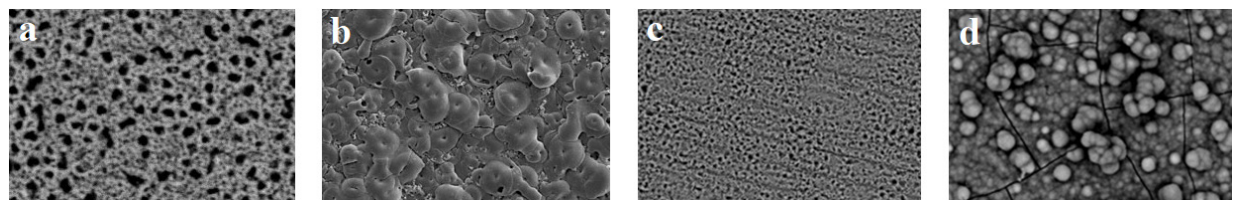

Fig.1. $\mathrm{PEO} \mathrm{TiO}_{2}$ coatings without and with particle addition $(\mathbf{a}, \mathrm{b})$, before and after SBF tests $(\mathbf{c}, \mathbf{d})$

References:

[1] Krząkała, A., Kazek-Kęsik, A, Simka, W. Application of plasma electrolytic oxidation to bioactive surface formation on titanium and its alloys. RSC Advances, 2013, 43, 19725-19743. 


\title{
DETERMINATION OF 5-HYDROXYINDOLEACETIC ACID IN WASTEWATER SAMPLES FROM WASTEWATER TREATMENT PLANTS IN LATVIA
}

\author{
Laura Elīna Ikkere ${ }^{1,2}$, Iveta Pugajeva ${ }^{1}$ \\ ${ }^{1}$ Institute of Food Safety, Animal Health and Environment "BIOR", Lejupes iela 3, Riga, \\ Latvia \\ ${ }^{2}$ University of Latvia, Faculty of Chemistry, Jelgavas iela 1, Riga, Latvia \\ e-mail: ikkere.laura@gmail.com
}

The wastewater analysis has the potential to provide objective information on the community drug usage pattern. Moreover, it has been shown recently, that wastewater-based epidemiology can be used as an early detection system for the determination of the scale of local COVID-19 outbreaks [1].

Introducing a population biomarker in the sample analysis may significantly reduce errors in the back-calculation associated with population estimation and wastewater volume measurement. 5-hydroxyindoleacetic acid (5-HIAA) is the main metabolite of serotonin in human organism. Due to its endogenous origin and other criteria, such as ease of measurement and negligible degradation, it is recognized by various authors as a suitable population biomarker in wastewater-based epidemiology [2].
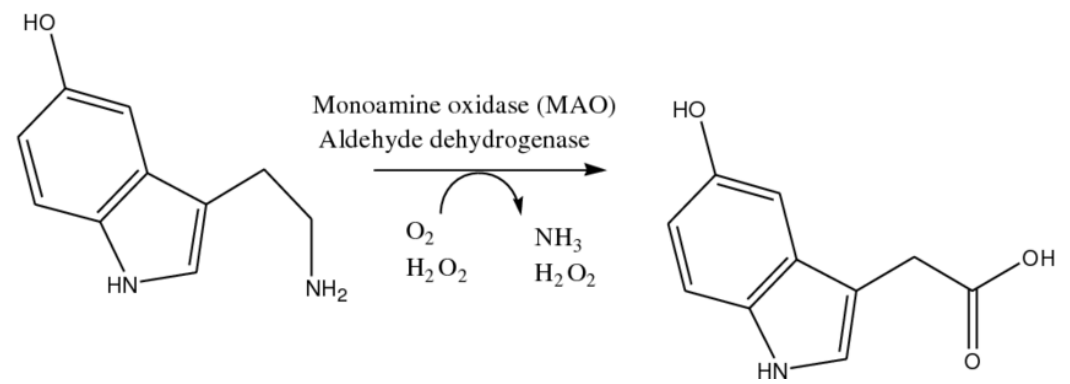

Fig. 1. Serotonin metabolized to 5-hydroxyindoleacetic acid

In the present study the sample preparation method for the determination of 5-HIAA in untreated wastewater was developed and optimized by comparing various solid phase extraction columns and extraction conditions. Quantitation was performed by UHPLC-Orbitrap-HRMS. The developed method was applied to more than 70 wastewater samples collected from five wastewater treatment plants in Latvia during 2020.

The research was part of project "Elaboration of new methodology using ultra high-resolution mass spectrometry for assessing public health via wastewater-based epidemiology" (Nr. lzp-2020/2-0150) funded by Latvian Council of Science.

\section{References:}

[1] Daughton C. G. Wastewater surveillance for population-wide Covid-19: The present and future. Sci. Total Environ. 2020, 736.

[2] Choi, P. M., Tscharke, B. J., Donner, E., O’Brien, J. W., Grant, S. C., Kaserzon, S. L., Kaserzon S. L., Mackie R., O’Malley E., Crosbie N. D., Thomas K. V., Mueller, J. F. Wastewater-based epidemiology biomarkers: Past, present and future. Trends Analyt. Chem. 2018, 105, 453-469. 


\title{
EXPERIMENTS ON LITHIUM CPS IRRADIATION AT THE IVG1.M RESEARCH REACTOR
}

\author{
Inesh Kenzhina ${ }^{1 \star}$, Saulet Askerbekov ${ }^{1,2}$, Yuriy Ponkratov ${ }^{3}$, \\ Yuriy Gordienko3 ${ }^{3}$, Irina Tazhibayeva ${ }^{3}$, Kairat Kadyrzhanov², \\ Yevgen Chikhray ${ }^{1}$ \\ ${ }^{1}$ Al-Farabi Kazakh National University, al-Farabi ave, 71, Almaty, Kazakhstan \\ ${ }^{2}$ L. N. Gumilyov Eurasian National University, 2, Satpayev str., Astana, Kazakhstan \\ ${ }^{3}$ National Nuclear Center of the Republic of Kazakhstan, 10, Beybit Atom str., Kurchatov, \\ Kazakhstan \\ e-mail:saulet@mail.ru
}

The results of the experiments on hydrogen isotopes interaction with lithium capillary-porous systems (CPS) under reactor irradiation are presented. A special ampoule device with a lithium CPS sample was designed for experiments at the IVG.1M research reactor (Kurchatov). The experiments were carried out by the method of dynamic sorption: a constant flow of deuterium was swept through the tube sample with constant degassing and registration of gas composition in the experimental ampoule device. The initial data on temperature dependencies of tritium release from lithium CPS under reactor irradiation is presented. The preliminary analysis showed some features of tritium release: insignificant tritium release occured in solid lithium (samples temperature below $180{ }^{\circ} \mathrm{C}$ ), tritium release decreased under temperature of cell's center of $\sim 250{ }^{\circ} \mathrm{C}$, tritium release stopped under temperature of cell's center $\sim 30{ }^{\circ} \mathrm{C}$; then tritium release increased with increase of temperature. The conclusion was made that tritium capture by lithium has a significant influence on the processes of tritium release from lithium CPS under reactor irradiation.

The work is supported by the Ministry of Education and Science of the Republic of Kazakhstan with Grant No. AP08856056. 


\section{APPLICATION OF CHEMOMETRIC METHODS FOR ASSESMENT OF MONOFLORAL AND POLYFLORAL HONEY}

\section{Krišs Dāvids Labsvārds',2, Lauma Buša', Jānis Ruško², Rihardș Klūga', Māris Bērtiņš', Jevgeṇija Naumenko', Vita Rudoviča', Marina Šalajeva', Arturs Vīksna ${ }^{1}$}

${ }^{1}$ University of Latvia, Faculty of Chemistry, Jelgavas iela 1, Riga, Latvia

${ }^{2}$ Institute of Food Safety, Animal Health and Environment "BIOR", Lejupes Street 3, Riga, Latvia

e-mail: kriss_davids.labsvards@lu.lv

Demand of honey in EU is larger than EU can produce so large part is imported and consumers have rights to be informed about their product fully as possible. In order to inform consumers isotope masspectrometry, chromatography, nuclear magnetic resonance, infrared spectroscopy and chemometric methods are performed to do that [1].

60 honey samples from origins of Latvia were analysed. Isotope ratio mass spectrometry (IRMS) was performed to determine carbon and nitrogen isotope ratio. Liquid chromatography high performance mass spectrometry (LC-HRMS) was performed to quantify 18 different polyphenols. NMR working frequency of $300 \mathrm{MHz}$ for ${ }^{1} \mathrm{H}$ was performed to acquire ${ }^{1} \mathrm{H}-\mathrm{NMR}$ spectra from 0 to $10 \mathrm{ppm}$ with bin width of $0,005 \mathrm{ppm}$. FT-IR spectrum was acquired using attenuated total reflectance (ATR) mode.

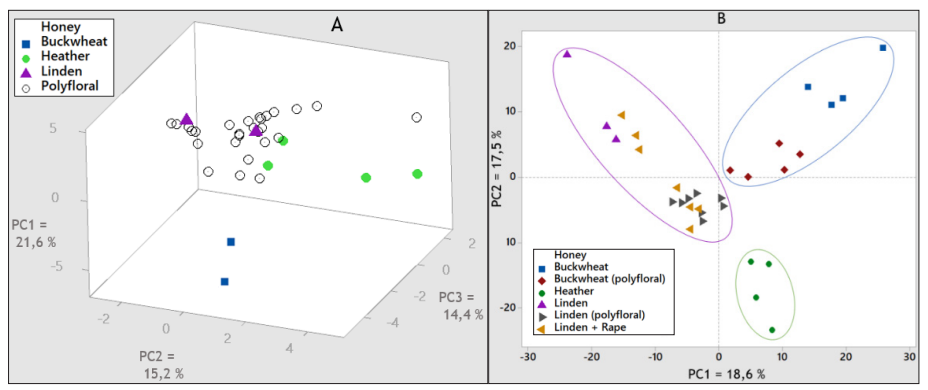

Fig. 1. A) 3D scatterplot construed from principal component values of $\delta^{13} \mathrm{C}$ values and polyphenol concentrations of monofloral buckwheat, heather, linden and polyfloral honey,

B) $2 \mathrm{D}$ scatterplot construed from principal component values of ${ }^{1} \mathrm{H}-\mathrm{NMR}$ spectra of monofloral and polyfloral honey.

The preliminary results show that the $\delta^{15} \mathrm{~N}$ values might be useful indicator for heather honey due values were statistically different after ANOVA one way test but all data from IRMS in combination with LC-HRMS results of concentrations of polyphenols could be useful way how to do assessment of honey for buckwheat and heather honey. Construed principal component scatterplots form ${ }^{1} \mathrm{H}-\mathrm{NMR}$ data shows best results to potentially distinguish monofloral from polyfloral honey and do assessment of botanical origin of polyfloral honey.

\section{References:}

[1] Consonni, R.; Bernareggi, F.; Cagliani, L. R. NMR-based metabolomic approach to differentiate organic and conventional Italian honey. Food Control 2019, 98, 133-140.

Acknowledgements: This work was supported by grant "Recognition of monofloral honey of Latvian origin using nuclear magnetic resonance, chromatographic, isotope ratio mass spectrometry and chemometric methods" grant Nr. LZP-2020/2-0200 


\title{
ELECTROCHEMICAL PROCESS IN SINGLE-WALLED CARBON NANOTUBES (SWCNT) FROM AQUEOUS SOLUTION
}

\author{
Vitālijs Lazarenko',2, Yelyzaveta Rublova², Raimonds Meija², \\ Jana Andžāne ${ }^{2}$, Vanda Voikiva², Edijs Kauranens ${ }^{2}$, Arturs Vīksna³ \\ Donāts Erts² \\ ${ }^{1}$ Nano RAY-T, Instituta iela 36-17, Riga, Latvia \\ ${ }^{2}$ Institute of Chemical Physics, University of Latvia, Jelgavas iela 1, Riga, Latvia \\ ${ }^{3}$ University of Latvia, Faculty of Chemistry, Jelgavas iela 1, Riga, Latvia \\ e-mail:vitalijs.lazarenko@lu.lv
}

In the last decade, lithium-ion batteries (LIBs) have dominated the world market as the most efficient batteries which are used in portable devices. However, the improper choice of solvent may be one of the reasons for lithium-ion battery failure that can cause explosive or combustion. Aqueous rechargeable lithium-ion batteries (ARLBs) have attracted the researcher's attention since 1994. ARLBs use an aqueous electrolyte which consists of lithium salt $\left(\mathrm{LiNO}_{3}, \mathrm{Li}_{2} \mathrm{SO}_{4}, \mathrm{LiCl}\right)$ and water. Lithium nitrate is considered the most electrochemically stable electrolyte [1].

Carbon nanotubes (CNT) have shown great potential as an anode electrode material for LIBs. They are unique materials in the field of nanotechnology due to their structural, mechanical, and electrical properties. CNT reduces lithium-ion diffusion and ensures excellent conductivity of electrons [2]. However, the detailed study of anode electrodes in ARLBs (especially CNT) is limited. Analysing several articles related to the CNT in the ARBLs shows that multi-walled carbon nanotubes (MWCNT) were studied more than single-walled carbon nanotubes (SWCNT). In those articles, CNT was used as a binder for anode electrodes $\left(\mathrm{TiP}_{2} \mathrm{O}_{7} / \mathrm{CNT}\right.$, $\mathrm{LiTi}_{2}\left(\mathrm{PO}_{4}\right)_{3} / \mathrm{C} / \mathrm{CNT}$, etc.). Unfortunately, there is no information about studies principally on CNT in the aqueous electrolytes.

The aim of the work was investigation of $\mathrm{Li}^{+}$intercalation/deintercalation processes in the SWCNT from the aqueous electrolyte. To reach this goal we used cyclic voltammetry (CV) and electrochemical impedance spectroscopy (EIS) analysis methods. SWCNT ( $\mathrm{d}=5-44 \mathrm{~nm})$ that was sprayed on the glass and pattered with gold $(60 \mathrm{~nm})$ and titanium $(5 \mathrm{~nm})$ to ensure electrochemical contact. As an electrolyte were used $5 \mathrm{M} \mathrm{LiNO}_{3}$ (Thermo Fischer, purity $99 \%$ ). CV and EIS were measured using a potentiostat (Autolab PGSTAT 30) and the 3-electrode system: $\mathrm{Ag} / \mathrm{AgCl}(\mathrm{RE})$, platinum electrode (CE), and SWCNT (WE). CV curves were measured at the following parameters: scan rate $0.5 \mathrm{mV} / \mathrm{s}$, potential range $(-0.5$ to 0.5 $\mathrm{V})$, and 5 cycles. EIS spectra were measured at the lithium intercalation potential.

From CV curves were determined two peaks responding for $\mathrm{Li}^{+}$intercalation/ deintercalation into SWCNT material and with each new cycle the intensity of peaks increases. The obtained EIS spectra show $\mathrm{Li}^{+}$diffusion in the CNT material.

Acknowledgement: This work was supported by European Regional Development Fund Project No. 1.1.1.1/19/A/139 "Development of innovative binder-free anode electrodes for lithium-ion batteries".

\section{References:}

[1] Chang, Z., Li, C., Wang, Y., Chen, B., Fu, L., Zhu, Y., Zhang, L., Wu, Y., \& Huang, W. (2016). A lithium ion battery using an aqueous electrolyte solution. Scientific Reports, 6, 2-7. https://doi.org/10.1038/srep28421.

[2] Jin, R., Sun, M., \& Li, G. (2017).CNTs@C@Bi2Se3 composite as an improved-performance anode for lithium ion batteries. Ceramics International, 43(18), 17093-17099. https:// doi.org/10.1016/j.ceramint.2017.09.124. 


\title{
IMPACT OF SEWAGE SLUDGE ON ELEMENTAL CONTENT IN PINE STEM WOOD
}

\author{
Katrina Lovcova', Maris Bertins', Dagnija Lazdina² Signija Zake', \\ Arturs Viksna ${ }^{1}$ \\ ${ }^{1}$ University of Latvia, Faculty of Chemistry, Jelgavas iela 1, Riga, Latvia \\ ${ }^{2}$ Latvian State Forest Research Institute 'Silava', 111 Rigas Street, LV-2169, Salaspils, Latvia \\ e-mail: Katrina.Lovcova@lu.lv
}

Scots pine (Pinus sylvestris L.) is one of the most important trees in forestry. Pulp and sawn timber products are made from pine wood. A pine seedling stand can be established by planting, sowing, or by the means of natural regeneration. The rotation of pine tree plantation is usually between 50 and 120 years. Pine is also used for the manufacture of turpentine, balsam, rosine, tar, coal, and other products used in medicine. Depending on the soil tillage technique applied, large amounts of macro-elements (N, P, K) and significant amounts of heavy metals and micro-elements can be introduced to soil and therefore be accumulated by a pine trees. A long growth time of pine gives the opportunity to study an impact from the used soil improvement method by analyzing elemental content in pine tree rings during all its lifespan.

Every year in Latvia there is produced more than $20000 \mathrm{t}$ of sewage sludge and only $30 \%$ of this amount is used in agriculture. Sewage sludge also could be used in forests and for recultivation of marginal lands. One of the aspects that worries about the use of sewage sludge is its possible contamination of heavy metallic elements.

The main aim of this study was to estimate the impact of used sewage sludge on elemental content distribution in pine stem plane and across tree rings.

Inductively coupled plasma mass spectrometry (ICP-MS) and isotope ratio mass spectrometry (IRMS) methods were used to determine the elemental concentration in different parts of pine. Stem disc samples were collected from fourteen-year-old pine trees growing in depleted peat deposit in the central part of Latvia (Hemi-boreal climate conditions) where sewage sludge was applied for soil improvement.

The obtained results of element content in the pine tree rings make it possible to determine the exact time of changes in environmental conditions which in this case is the time when sewage sludge was applied. The analyzed elements varied not only in the analyzed stem plane (across the tree rings) but also in different heights of pine stem. But regardless of changes in other element content between tree rings, significant changes in potassium and calcium content are observed even when environmental conditions have not changed. A decrease of $\mathrm{Ca}$ and increase of $\mathrm{K}$ content in newer tree rings was observed. 


\title{
SEPERATION OF CRANBERRY PROCYANIDINS USING BIOLOGICAL ACTIVITY GUIDED FRACTIONATION
}

\author{
Mārcis Mežulis', Linards K!̣aviṇš', Inguss Pērkons², \\ Vadims Bartkevičs ${ }^{2}$, Arturs Viksna ${ }^{3}$, Māris Kḷaviṇš ${ }^{1}$ \\ ${ }^{1}$ University of Latvia, The Natural Resource Research Centre, Jelgavas street 1, Riga, Latvia \\ 2 Institute of Food Safety, Animal Health and Environment "BIOR", Lejupes street 3, Riga, \\ Latvia \\ ${ }^{3}$ University of Latvia, Faculty of Chemistry, Jelgavas street 1, Riga, Latvia \\ e-mail:marcis.mezulis@lu.lv
}

Antioxidants are substances that prevent undesirable reactions occurring in human organism. The most valuable of these compounds are polyphenolics and procyanidins, which in traditional medicine, have helped in prevention of urinary tract inflammation as well as cardiovascular and heart diseases. Recent studies of procyanidin activities concentrate on anticancer activity where positive effects against breast cancer cell lines are shown [1].

The aim of this study was to optimise extraction of procyanidins from cranberry press residues using different solvent systems. Following extraction optimisation, procyanidins were fractionated using a newly developed three-step SPE purification method. Spectrometric analyses, HPLC-UV/Vis, FT-ICR-HRMS, HPLC-MS/MS were carried out to determine the composition of the fractions (Fig. 1.), as well as analyses to determine relevant biological activity.

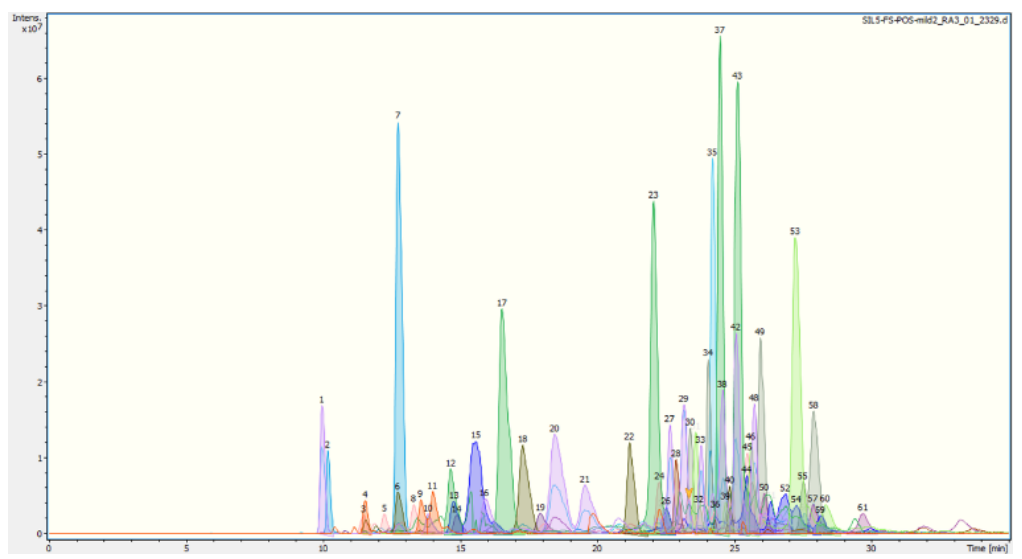

Fig. 1. Qualitative study of procyanidin extract using FT-ICR-HRMS

The preliminary results show that the $70 \%$ acetone-based solvents yield the highest procyanidin concentration in extracts, and fractions containing strictly procyanidins can be obtained using the developed SPE chromatography method, which will be used in further microbiological and other in vitro studies.

\section{References:}

[1] Koteswari L. L., Kumari S., Kumar A. B., Malla R. R. A comparative anticancer study on procyanidin Clagainst receptor positive and receptor negative breast cancer. Nat. Prod. Res. 2019, 34:22, 3267-3274. 


\title{
EVALUATION OF THE CHEMICAL COMPOSITION OF MACRO- AND MICRO- ELEMENTS IN THE BOTTOM AND FLY WOOD ASH
}

\author{
Megija Neimane', Vitālijs Lazarenko², Māris Bērtin̨š', Arturs Vīksna', \\ Dagnija Lazdiṇa², Kristaps Makovskis² ${ }^{2}$ Ilze Kārkliṇa², Andis Lazdiṇš ${ }^{2}$ \\ ${ }^{1}$ University of Latvia, Faculty of Chemistry, Jelgavas iela 1, Riga, Latvia \\ ${ }^{2}$ Latvian State Forest Research Institute "Silava", Rīgas iela 111, Salaspils, Latvia \\ e-mail:megijaneimanee@gmail.com
}

Wood ash is biomass that is produced in the combustion process of wood and its products (wood chips, bark, shavings, etc.). During the combustion process $6-10 \%$ of ash from the total wood mass are formed. The physical properties and chemical composition of wood ash depend on the production process itself. Wood ash may contain macro-, micro- and rare earth elements.

Wood ash is divided into three main types: fly ash, bottom ash and mixed ash. Bottom ash is the coarse granulated fraction with particle size $0.4-4.7 \mathrm{~mm}$ which contains impurities (stones sans, etc.). Fly ash is the fine wood ash fraction with particle size $0.3-250 \mu \mathrm{m}$. Mixed wood ash contains both bottom and fly ash.

In several countries of European Union, wood ash is used for construction of roads, where wood ash is used in the place of cement in asphalting. Wood ash can be used as a fertilizer for agricultural and forest lands as it contains a high amount of macro- and micro- elements. However, several studies concluded, that wood ash also contains heavy metallic elements.

It is necessary to utilize wood ash and create a biocycle to significantly increase the amount of renewable energy produced using biomass in the future. Using wood ash, we return to nature small part of what we have taken. The use of biomass for energy will not only reduce $\mathrm{CO}_{2}$ emissions but also better protect the environment.

The aim of this research was to evaluate macro- and micro- element content in the bottom and fly wood ash. Both types of wood ash samples were collected in 2014 from the different parts of Latvia from boiler houses. The samples were extracted in $5,00 \mathrm{~mL}$ of concentrated $\mathrm{HNO}_{3}$ shaken for 5 hours (190 rpm), then diluted to $20 \mathrm{~mL}$ with deionized water $\left(<0.055 \mu \mathrm{S} . \mathrm{cm}^{-1}\right)$. The resulting solution was filtered (Whatman 541) and the content of macro- and micro- elements was determined by the ICP-MS (Agilent 8900 QQQ) analysis method.

Results show that the concentration of macroelements varies in the wide range and it is not dependent on the type of wood ash. The content of Al, Mn, Zn, Cd and $\mathrm{Pb}$ are higher in the fly ash than bottom ash. However, the content of $\mathrm{Cr}, \mathrm{V}$ and $\mathrm{As}$ are higher in the bottom ash. 


\title{
METHODS FOR SEPARATION OF LIPOPHILIC COMPOUNDS TO PURIFY ORGANOSOLV LIGNIN ISOLATED FROM ASPEN BARK.
}

\author{
Matīss Pāls' ${ }^{1,2}$, Aleksandrs Aršaṇica ${ }^{2}$, Arturs Viksna ${ }^{1}$ \\ ${ }^{1}$ University of Latvia, Faculty of Chemistry, Jelgavas iela 1, Riga, Latvia \\ ${ }^{2}$ Latvian State Institute of Wood chemistry, Dzerbenes iela 27, Riga, Latvia \\ e-mail:matiss232@gmail.com
}

Residual bark, after non lignin phenolic extraction, is a valuable resource suitable for further fractionation in terms of effective lignin and carbohydrates obtaining. A promising environmentally friendly approach for residual bark processing is Organosolv delignification using alcohols-water mixtures as a solvent. That although has been described in literature for quite some time now, relatively little has been done in terms of tree bark Organosolv delignification.

The results obtained has shown that utilising of Organosolv delignification approach using butanol-water solution it is possible to separate lignin from residual aspen bark with low degree of condensation and high amount of reactive functional groups making its prospective for chemical modification. But the nonlignin compounds presented in separated lignin fractions as an admixture will creates the difficulties in its further valorisation pathways.

Analytical pyrolysis data has shown, that lipophilic compounds is the dominant group of admixtures presented in separated aspen bark lignin fraction. To purify isolated lignin, two separate pre-treatment options were tested as shown in Figure 1.

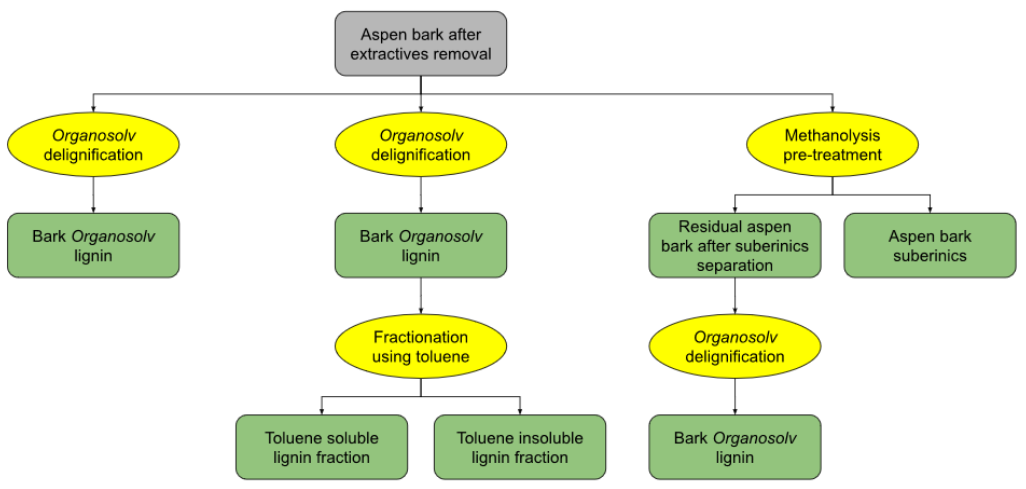

Fig 1. Proposed pathways for lipophilic admixtures removal.

First method involves fractioning obtained Organosolv lignin using toluene to obtain toluene soluble fraction, consisting mainly of lipophilics and toluene insoluble fraction as lipophilic free lignin. Second method involves performing bark pre-treatment to separate suberinic fraction before delignification. To do this methanolysis was used, treating bark in potassium methoxide solution to separate lipophilic fraction. Afterwards obtained residual bark was delignified as before, and lignin sample was obtained. The compositions of lignin purified by by both methods was characterised by FTIR and PY-GC/MS spectroscopies in terms of admixtures content. 


\title{
CONTAMINATION OF FOODSTUFFS WITH PER- AND POLIFLUORALKYL SUBSTANCES
}

\author{
Elina Pasecnaja ${ }^{1,2}$, Dzintars Zacs ${ }^{2}$ \\ ${ }^{1}$ University of Latvia, Faculty of Chemistry, Jelgavas iela 1, Riga, Latvia \\ ${ }^{2}$ Institute of food safety, animal health and environment "BIOR", Lejupes iela 3, Riga, \\ Latvia \\ e-mail: elina.pasecnaja@bior.lv
}

Per- and polyfluorinated alkyl substances (PFASs) comprise a large group of anthropogenic chemicals which are ubiquitous environmental contaminants. PFASs have been produced for over 60 years and are widely used for many industrial purposes and consumer-related applications. Their properties such as high chemical stability, resistance to heat and abrasion, low surface free energy, surface-active properties, and oil-, water-, and stains-repellence attract wide use of PFASs for various purposes in our everyday lives. Applications of PFASs include food packaging, nonstick cookware and stain repellents (such as Teflon), cleaning agents, surfactant, coating materials, textiles, carpets, upholstery, leather, waxes, polishes, adhesives, paints, cosmetics, electronics, aviation hydraulic fluids, fire-fighting materials and paper [1].

PFASs can enter the human organism through skin and the digestive and respiratory systems, where they are not metabolized and removed from the body. High absorption level and low elimination rates of PFASs are observed in living organisms. Estimated geometric half-lives in human body of PFAS representativesperfluorooctane sulfonate (PFOS), perfluorooctanoate acid (PFOA) and perfluorohexane sulfonic acid ( $\mathrm{PFHxS}$ ) are 4.8 years, 3.5 years and 7.3 years, respectively. Therefore, the long half-life of PFASs in human body may potentially cause various health problems. Hepatotoxicity, developmental toxicity, immunotoxicity, hormonal effects and a carcinogenic potency are the effects of main concern [2].

European Food Safety Authority (EFSA) in 2020 established a tolerable weekly intake (TWI) of $4.4 \mathrm{ng} / \mathrm{kg}$ bw per week for the sum of four PFASs:PFOA, perfluorononanoic acid, PFHxS and PFOS. Occurrence data is needed for all PFASs found in the environment and in a broad range of widely consumed food products. Therefore, in order to get comprehensive PFAS occurrence data for food, more sensitive and accurate analytical methods with high levels of quality control are needed. [3].

\section{References:}

[1] Domingo J. L., Nadal M. Per- and polyfluoroalkyl substances (PFASs) in food and human dietary intake: A review of the recent scientific literature J. Agric. Food Chem. 2019, 65, 533-543.

[2] Olsen G. W., Burris J. M., Ehresman D. J., Froelich J. W., Seacat A. M., Butenhoff J. L., Zobel L. R. Half-life of serum elimination of perfluorooctanesulfonate, perfluorohexanesulfonate, and perfluorooctanoate in retired fluorochemical production workers Environ. Health Perspect. 2007, 115, 1298-1305.

[3] Schrenk D., Bignami M., Bodin L., Chipman J. K., del Mazo J., Grasl-Kraupp B., Hogstrand C., Hoogenboom L., Leblanc J. C., Nebbia C. S., Nielsen E., Ntzani E., Petersen A., Sand S., Vleminckx C., Wallace H., Barregård L., Ceccatelli S., Cravedi J. P., Halldorsson T. I., Haug L. S., Johansson N., Knutsen H. K., Rose M., Roudot A. C., Van Loveren H., Vollmer G., Mackay K., Riolo F., Schwerdtle T. Risk to human health related to the presence of perfluoroalkyl substances in food EFSA Journal 2020, 18. 


\title{
OPTIMISATION OF THE SAMPLE PREPARATION STRATEGY FOR THE ANALYSIS OF MYCOTOXINS IN WASTEWATER SAMPLES
}

\author{
Romans Pavḷenko', 2, Zane Bērziṇa ${ }^{1,2}$, Estefānija Bogdanova', ${ }^{1,}$ \\ Mārtiņ̧̌ Jansons ${ }^{2}$, Vadims Bartkevičs ${ }^{1,2}$ \\ ${ }^{1}$ University of Latvia, Faculty of Chemistry, Jelgavas iela 1, Riga, Latvia \\ 2 Institute of Food Safety, Animal Health and Environment "BIOR", Lejupes iela 3, \\ Riga LV-1076, Latvia \\ e-mail: romans.pavlenko@bior.lv
}

Mycotoxins are toxic compounds naturally produced by a certain type of fungi that grow on foodstuffs such as cereals, dried fruits, nuts, and spices. Most mycotoxins are chemically stable, they survive storage and processing, and could even remain in cooked food, so humans are mainly exposed through direct ingestion of contaminated foods and, therefore, certain amounts of mycotoxins are transferred to the samples of wastewater (WW) as a result of excretion [1]

Within the current study the main parameters of the analysis were optimised for the determination of 13 main regulated mycotoxins in WW samples. Quadrupole tandem mass spectrometry was selected for the quantification of these compounds. $0.1 \%$ formic acid solutions in water and methanol were selected as a mobile phase for liquid chromatography. Our results showed that additional salts in the mobile phases did not significantly improve the determination of the selected compounds.

Five solid phase extraction (SPE) columns (Strata X, Strata-C18, Oasis HLB, Strata Basic Screen, and Strata ABW) were compared. The best recovery for deoxynivalenol (DON) was achieved using the Oasis HLB phase, however, recoveries for the other compounds were much lower. Strata Basic Screen and Strata X SPE columns showed the acceptable results for other mycotoxins, however, using Strata Basic Screen it was impossible to retain DON and C18 indicated better recoveries for less polar compounds. Strata X SPE columns showed better retention for more polar ones but also being usable for non-polar compounds. The detectable concentrations are in the range of 1,25-5 $\mathrm{ng} / \mathrm{L}$ for different mycotoxins. SPE activation, concentration, and equilibration steps were optimised. For polar mycotoxins, it was concluded that acetonitrile is provided better elution efficiency and for non-polar compounds $\mathrm{MeOH}$ was preferable.

The final version of the analytical procedure provided the limits of detection in the range of 1-5 $\mathrm{ng} / \mathrm{L}$ for different mycotoxins.

Acknowledgement: Project No. lzp-2020/2-0128 funded by the Latvian Council of Science.

\section{References:}

[1] Gracia-Lor, E.; Zuccato, E.; Hernández, F.; Castiglioni, S. Wastewater-Based Epidemiology for Tracking Human Exposure to Mycotoxins. J. Hazard. Mater. 2020, 382121108. 


\section{STUDIES ON THE COMPLIANCE OF WOODCHIP ASH WITH RADIATION SAFETY STANDARDS}

Daina Riekstiṇa ${ }^{1,2}$, M. Plūme ${ }^{3}$, V. Gostilo4 , Gunta Ķizāne $^{2}$

${ }^{1}$ Institute of Solid State Physics, University of Latvia

${ }^{2}$ Institute of Chemical Physics, University of Latvia

${ }^{3}$ SIA Dosimeter

${ }^{4}$ Baltic Scientific Instruments

e-mail:daina.riekstina@cfi.lu.lv

Artificial radionuclides ${ }^{137} \mathrm{Cs}$ and ${ }^{90} \mathrm{Sr}$ entered the forest ecosystem of Latvia and its neighbouring countries as pollution as a result of the accident at the Chernobyl nuclear power plant.

With the increase in the use of wood materials, especially wood chips, there is a growing interest in the level of contamination of artificial radionuclides in wood fuels and its ash after burning

Analysis of ${ }^{90} \mathrm{Sr}$ concentration in pine and spruce needles, as well as in the bark of various trees depending on the height above the ground was performed by radiochemical separation of ${ }^{90} \mathrm{Sr}$ decay daughter product isotope ${ }^{90} \mathrm{Y}$ and its activity by Cherenkov radiation measurements with Packard LSC TRI-CARB2770 beta spectrometer

Comparing ${ }^{90} \mathrm{Sr}$ concentration in pine, spruce and birch bark at different heights, it was found that the highest ${ }^{90} \mathrm{Sr}$ concentration is in spruce bark and the lowest - in birch bark, where the maximum ${ }^{90} \mathrm{Sr}$ concentration was observed at the corresponding tree trunk height $\sim 3 / 4$.

Gamma-spectrometry method was used to measure ${ }^{137} \mathrm{Cs}$ concentration in spruce needles, pine wood, wood chips and ash samples. The ash coefficients of the respective wood are also evaluated in the work.

Summarizing the results, it is concluded that the concentrations of ${ }^{137} \mathrm{Cs}$ and ${ }^{90} \mathrm{Sr}$ in the wood materials of Latvian origin do not exceed the level allowed by regulatory enactments, which cannot be said about the imported wood chips. 


\title{
SYNTHESIS AND APPLICATION OF FERROCYANIDES FOR EFFICIENT ADSORPTION OF CAESIUM ON CELLULOSE AND ITS DERIVATIVES
}

\author{
Kristine Saleniece ${ }^{1,2}$, Ugis Eismonts', 2 , Maris Bertins ${ }^{3}$, Olga Muter', \\ Sergejs Gaidukovs ${ }^{4}$, Arturs Vīksna ${ }^{3}$, Zenta Balcerbule ${ }^{1,3}$, \\ Gunta Kizane ${ }^{1}$, Ingars Reinholds ${ }^{1,3}$, Andrejs Grinbergs ${ }^{1}$ \\ ${ }^{1}$ Institute of Chemical Physics, University of Latvia, Jelgavas iela 1, Riga, Latvia \\ ${ }^{2}$ Faculty of Medicine, University of Latvia, Jelgavas iela 1, Riga, Latvia \\ ${ }^{3}$ Faculty of Chemistry, University of Latvia, Jelgavas iela 1, Riga, Latvia \\ ${ }^{4}$ Faculty of Material Science and Applied Chemistry, Institute of Polymer Materials, Riga \\ Technical University, P. Valdena 3/7, Riga, Latvia \\ e-mail: kristine.saleniece@lu.lv,ingars.reinholds@lu.lv
}

Caesium (Cs), the rarest of the naturally occurring alkali metals determines global concerns due to wide use of its radioactive derivatives in nuclear medicine, research laboratories, geology, and military field applications. The radioactive isotopes $\left({ }^{134} \mathrm{Cs}\right.$ and $\left.{ }^{137} \mathrm{Cs}\right)$, which are beta and gamma radiation emitters, possesses serios environmental and human threats due to the rather long half-life of ${ }^{137} \mathrm{Cs}$, high radioactivity and bioaccumulation potential.

The present study is related to development of efficient biomaterial-based adsorbents using combined cellulose membrane systems and ferrocyanide salts for the adsorption of Cs isotopes.

Three aspects of the research actuality are emphasized: a) adequate radiation protection of workers involving permanent work with Cs sources; b) individual safety aspects related to nuclear incidents and global threats to population; c) environmental issues on reducing nuclear wastes.

Poisoning with Cs in laboratory conditions or geological events may cause dramatical issues, because there are no antidotes available in Latvia comparing to other countries. For instance, the national US reserves include sorbent materials based on potassium ferric hexacyanoferrate salt (Prussian blue), and in other non-European countries. In Europe, there are registered products, while there are not available real protection materials for personnel or wider population groups. The aim of this work is to develop novel adsorbents of Cs isotopes using cellulose and its esters modified with ferrocyanide salts. That could help for prevention of Cs contamination through urban wastewater systems, including drinking water, and individual products such as milk and breast milk.

Within experimental part, different reaction routes for the synthesis of micro to nanoscale ferrocyanide salts were developed and characterised using spectroscopy and microscopy methods (FTIR, SEM, etc.).

Different commercial cellulose esters and available filter systems (e.g., face protection filters, baby bottle filters, etc.) are included in testing as potential matrices for Cs adsorption.

The preliminary study was conducted to evaluate adsorption potential of micro-scale ferrocyanide salts. Caesium, and strontium chloride water solutions $(0.1 \mathrm{mg} / \mathrm{ml}$ each) were used as model systems. The adsorption capacity was tested using $1 \mathrm{~g}$ of synthesized Prussian blue as a sorbent matrix. Sr salt was used as co-pollutant of beta emitter isotopes. The Langmuir adsorption model was used to determine the adsorption capacity. The concentrations of $\mathrm{Cs}$ and $\mathrm{Sr}$ in solution 
were tested after the transfer of Cs and Sr ion solvents through filters. Analysis using ICP-MS indicated that synthesized potassium ferric hexacyanoferrate was selective for Cs ions, which were fully adsorbed compared to Sr ions.

Further work will include synthesis and modification of cellulose surface for ${ }^{134} \mathrm{Cs}$ and ${ }^{137} \mathrm{Cs}$ adsorption. Work on the procedure optimisation is in the progress.

Acknowledgements: The research was funded from the Latvian Council of Science, project No lzp-2020/2-0213 "Application of modified cellulose fiber sorbents for concentration of radioactive hydrogen (tritium) and other radionuclides from contaminated environments and evaluation of toxic properties: approbation of the method for purification of water residues from nuclear reactors stored in Latvia." 


\title{
SHORT TERM VARIATIONS IN ELEMENT CONCENTRATIONS IN THE RHIZOSPHERE SOIL OF COUCH GRASS (ELYMUS REPENS) AND DANDELION (TARAXACUM OFFICINALE)
}

\author{
Irina Shtangeeva ${ }^{1}$, Arturs Viksna², Maris Bertins ${ }^{2}$ \\ ${ }^{1}$ Institute of Earth Sciences, St. Petersburg University, Universitetskaya nab., 7/9, \\ St. Petersburg, Russia \\ ${ }^{2}$ University of Latvia, Faculty of Chemistry, Jelgavas iela 1, Riga, Latvia \\ e-mail:shtangeeva@gmail.com
}

There is a variety of different interactions in soil between physical, chemical, and biological processes that is affecting its formation. The chemical composition including content of different macro- and trace elements in soil, is variable and are influenced by different conditions like rocks, climate, and plants presented at the site. The study of element uptake by plants and interaction between different plants and rhizosphere soil are very important in the environmental chemistry. Of course, in many cases these processes are not yet fully explored and understood. Currently, it is fundamentally important to gain insight into the factors that control exchange of various elements between rhizosphere soil and plants and to evaluate what processes takes place between rhizosphere soil and plant roots.

Root exudates are soluble organic compounds that are released from plants to soil. They are active in a very narrow zone near roots and can affect the characteristics of soil. It is known that root exudates can be released into space near roots as response to toxicity, stress, and microbial activity. The root exudates can directly affect carbon and nitrogen cycles. Even small variations that takes place in the system can lead to large scale changes in its functioning, since organic matter in soil is an important part of earthy ecosystems. Human knowledge about the processes that control root exudation and interaction between soil, plants, and microorganisms is scarce and that concerns especially temporal variability of the root exudation and makes impact on availability of macronutrients and trace elements.

In this experiment rubidium was used as a potentially toxic element. It was chosen because it is a chemical analogue of potassium which is an essential plant nutrient. Plants can uptake $\mathrm{Rb}$ which is also highly mobile and can be transferred to the aboveground parts of the plant.

The main aim of this study was to evaluate the impact of root exudates of two widely distributed plant species couch grass (Elymus repens) and dandelion (Taraxacum officinale) on the concentrations of macro- and trace elements in the rhizosphere soil of the plants.

A field trial was carried out in May 2019 in a park in St. Petersburg, Russia. The experimental area consisted of two plots located close to each other. Each plot was $2 \times 2$ m wide. One of the plots served as control plots and other was spiked with rubidium chloride (75 $\mathrm{mg} \mathrm{m} 2) 24$ hours before sampling. For the determination of element concentrations in samples were used element analyzer (EA Eurovector) and ICP-MS (Agilent 8900 ICP-MS QQQ).

Obtained results showed that total amount of $\mathrm{C}$ and $\mathrm{N}$ in the rhizosphere soil of both plant species decreased during daytime. Similar variations were also found for $\mathrm{Al}, \mathrm{As}, \mathrm{Ga}, \mathrm{Mg}$, and $\mathrm{V}$. The concentrations of $\mathrm{Ce}, \mathrm{La}, \mathrm{Na}$, and Se were highest in the middle of the day. These variations might be caused due to changes in the soil 
temperature. Contamination of the soil with $\mathrm{RbCl}$ negatively affected the concentrations of several elements in the rhizosphere soil of both plants. The impact was more grater when the plants grew further away from each other.

Acknowledgement: This work was supported by financial support from Programme of Exchange of Staff between St. Petersburg University and University of Latvia (Grant No. 7/3351) and a partial support of this work by Russian Foundation of Basic Research (Grant No. 18-53-80010). 


\title{
STORED CHARGE DETERMINATION OF SPARK PLASMA SINTERED AMORPHOUS CALCIUM PHOSPHATE
}

\author{
Dārta Ūbele1, Ints Šteins², Dagnija Valdniece', Aiga Anna Pudule', \\ Kārlis Agris Gross ${ }^{1}$ \\ ${ }^{1}$ Institute of Inorganic Chemistry, Riga Technical University, Paula Valdena street 3/7, \\ Riga, Latvia \\ ${ }^{2}$ Biomaterials Research Laboratory, Riga Technical University, Paula Valdena street 3/7, \\ Riga, Latvia \\ e-mail:darta.ubele@rtu.lv
}

Amorphous calcium phosphate (ACP), more precisely amorphous apatite, resembles the early stage of biomineralization in bone and teeth and shows potential for biomaterial applications. Since spark plasma sintering (SPS) can consolidate powders at low temperatures, it may retain the initial advantageous characteristics of the ACP materials [1].

ACP powders were pressed using SPS method at three different temperatures $\left(200,500,700{ }^{\circ} \mathrm{C}\right)$ allowing a comparison between amorphous and crystalline states. Phase and functional groups were analysed by x-ray diffraction (XRD) and Fourier-transform infrared spectroscopy (FTIR), respectively. Surface charge potential was evaluated by polarization in electrical field at elevated temperature and determined by thermally stimulated depolarization current (TSDC) measurements.
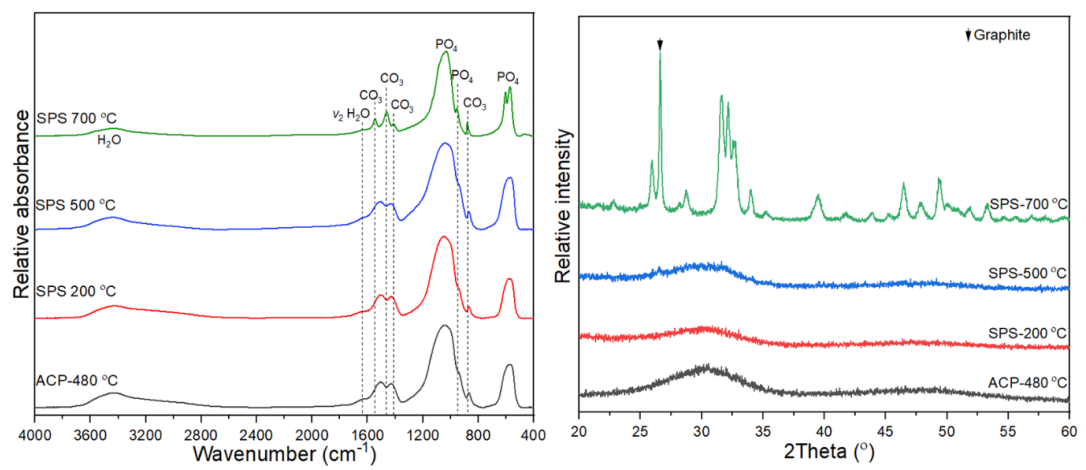

Fig. 1. FTIR spectra and XRD of ACP powder heated to $480^{\circ} \mathrm{C}$ and then SPSed $\left(200{ }^{\circ} \mathrm{C}\right.$ to $\left.700{ }^{\circ} \mathrm{C}\right)$

Preliminary results show that ACP materials prepared by SPS can store a surface charge of $4.8 \mu \mathrm{C} / \mathrm{cm}^{2}$ (when heated up to $500{ }^{\circ} \mathrm{C}$ ), but surface charge increase up to $7.5 \mu \mathrm{C} / \mathrm{cm}^{2}$ for crystalline (heating up to $700{ }^{\circ} \mathrm{C}$ ) material.

This work was supported by the Latvian Council of Science project, Freedom to Move, project No. 2018/01-0432. Authors thank the Faculty of Chemistry, University of Latvia, for providing access to FTIR spectroscopy.

\section{References:}

[1] D. Grossin, S. Rollin-Martinet, C. Estournes, F. Rossignol, E. Champion, C. Combes, C. Rey, C. Geoffroy, C. Drouet. Biomimetic apatite sintered at very low temperature by spark plasma sintering: Physico-chemistry and microstructure aspects. Acta Biomaterialia 6 (2010) 577-585 


\title{
EXTRACTION AND CHARACTERISATION OF WILD AND CULTIVATED INONOTUS OBLIQUUS TRITERPENOID AND ELEMENTAL PROFILES
}

\author{
Karina Upska ${ }^{1}$, Linards Klavins ${ }^{\star 1}$, Vizma Nikolajeva ${ }^{2}$, Leena Faven ${ }^{3}$, \\ Eveliina Isosaari $^{3}$, Arturs Viksna ${ }^{4}$, Maris Klavins ${ }^{1}$ \\ ${ }^{1}$ The Natural Resource Research Centre of the University of Latvia, Jelgavas iela 1, Riga, \\ Latvia \\ ${ }^{2}$ University of Latvia, Department of Microbiology and Biotechnology, Jelgavas iela 1, Riga, \\ Latvia \\ ${ }^{3}$ Centria University of Applied Sciences, Chemistry and Bioeconomy research team, \\ Talonpojankatu,67100, Kokkola, Finland \\ ${ }^{4}$ University of Latvia, Faculty of Chemistry, Jelgavas iela 1, Riga, Latvia \\ e-mail: karina.upska@lu.lv
}

Chaga (Inonotus obliquus) (Fr.) Pilát is a black perennial fungus of the Hymenochaetaceae family that parasites on adult birch trunks as well as on other types of broadleaf tree species - alder, mountain ash. Inonotus obliquus produces a wide range of bioactive metabolites, including triterpenoids, sterols, polysaccharides, polyphenols. These compounds have antioxidant, antitumor, and antiviral activity and the ability to increase immunity to pathogenic microbial infections. Inonotus obliquus can be not only found in natural environment, but also be cultivated on different substrates using malt, birch saw dust, grain and potato dextrose agar.

To the best of our knowledge, until now no other works have explored the difference in the lipophilic composition of chaga depending on its origin. The aim of this study was to isolate chaga lipophilic compounds by different extraction methods using different non-polar solvents to obtain the maximum extraction yield, authentificate chaga samples using isotope ratio mass spectrometry (IRMS) and multi-elemental analysis, compare lipophilic compositions of different origin and its effect on pathogenic microorganisms to evaluate potential applications of chaga extracts.

Acknowledgements: This work was supported by the Interreg project R079 "NovelBaltic Market Driven Authentic Non-timber Forest Products from the Baltic Sea Region". 


\title{
APPLICATION OF $\triangle 15 N$ VALUES IN STUDIES OF NITROGEN CYCLE IN PINE TREE (PINUS SYLVESTRIS L.)
}

\author{
Signija Zake', Maris Bertins¹, Dagnija Lazdina², Karlis Dumins², \\ Arturs Viksna ${ }^{1}$ \\ ${ }^{1}$ University of Latvia, Faculty of Chemistry, Jelgavas iela 1, Riga, Latvia \\ ${ }^{2}$ Latvian State Forest Research Institute 'Silava', 111 Rigas Street, LV-2169, Salaspils, Latvia \\ e-mail:Signija.Zake@lu.lv
}

Nitrogen is one of the most important elements in every living organism. It's also the most abundant element in the earth's atmosphere (78\%). Nitrogen is found in all animal and plant proteins. Nitrogen is not available for plants directly from the atmosphere. Its generally taken up by plants in form of nitrates or ammonia from the soil, that is the reason fertilization or soil improvement with ammonia and nitrate-containing compounds. But there is also the possibility to improve soil using amino acids, for example, arginine which plants tend to uptake even more easily than ammonia and nitrogen compounds.

For many years now ratios of ${ }^{14} \mathrm{~N}$ and ${ }^{15} \mathrm{~N}$ are used as indirect parameters for nitrogen cycle studies. Usually in these studies' nitrogen isotopes are determined in plants' stems and leaves. With the development of industry natural pollution is felt in all places. Different production processes, chemical waste, mineral fertilizers, and other various processes influence the balance of nitrogen isotopes in the environment, so it is very important to choose a less polluted site for research - forest.

The main aim of this study was to evaluate the impact of the use of arginine for soil improvement in the forest areas on the nitrogen cycle and changes in $\mathrm{d}^{15} \mathrm{~N}$ values in pine needles.

In the research were analyzed arginine, soil, and pine needle samples from the forest field where arginine was used for soil improvement. The analyses were carried out with Isotope Ratio Mass Spectrometry (IRMS, EA Eurovector $+\mathrm{Nu}$ Horizon) at the University of Latvia, using certified inorganic reference materials USGS-40 and USGS-41 (L-Glutamic acid). The $\delta^{15} \mathrm{~N}$ values were expressed relative to air.

Light Stable Elemental isotope ratio mass spectrometry is a method, which allows determining the ratio of nitrogen, carbon, hydrogen, oxygen, and sulfur isotopes in different plants and parts of it. From the obtained isotope ratio values, it is possible to make conclusions about the nitrogen cycle, photosynthesis processes, and growing conditions (temperature, climate) of the plants. $\mathrm{N}$ isotope values can be used to determine the source of nitrogen - does it comes from the soil, soil additive (fertilizer, improver), or air. And IRMS is the method with which could be evaluated the effect of this procedure.

Results of this research showed that after treatment with arginine there was no significant increase in the mass fraction of nitrogen in pine needles $-\mathrm{wN}$ values were in the range from 1-2\%. But IRMS measurements showed a clear impact of soil improvement with arginine, $\mathrm{d}^{15} \mathrm{~N}$ values in pine needles decreased and become more closer to values in the used arginine source $\left(-2,1 \% o_{\text {air }}\right)$.

Acknowledgement: This work was supported by Short term scientific mission organized in scope of project "Research program for improving tree growth conditions 2016-2021". 


\title{
PRELIMINARY EXPERIMENTS FOR STUDYING OF LITHIUM CERAMICS INTERACTION WITH NEUTRON IRRADIATION USING VACUUM EXTRACTION METHOD
}

\author{
Zhanna Zaurbekova $^{1 \star}$, Gunta Kizane ${ }^{2}$, Timur Kulsartov', \\ Asset Shaimerdenov', Saulet Askerbekov ${ }^{1,3}$, Assyl Akhanov³, \\ Yevgen Chikhray ${ }^{1}$ \\ ${ }^{1}$ Al-Farabi Kazakh National University, al-Farabi ave, 71, Almaty, Kazakhstan \\ ${ }^{2}$ Institute of Chemical Physics, University of Latvia, Jelgavas iela 1, Riga, Latvia \\ ${ }^{3}$ Institute of Nuclear Physics, 1, Ibragimov str., Almaty, Kazakhstan \\ e-mail:zzha@mail.ru
}

Lithium ceramics in the form of pebbles is considered as a prospective tritium-breeding material for use in fusion reactors. Advanced ceramic breeder pebbles consisting of monoclinic lithium orthosilicate $\left(\mathrm{Li}_{4} \mathrm{SiO}_{4}\right)$ as the primary phase and monoclinic lithium metatitanate $\left(\mathrm{Li}_{2} \mathrm{TiO}_{3}\right)$ as the secondary phase are a potential material for ITER and DEMO fusion reactors. During operation, breeder ceramics will be under action of elevated temperatures, magnetic field, ionizing radiation and intense neutron radiation.

Study of tritium generation and release from lithium ceramics is an actual issue faced the researchers, because experiments should be carried out "in-situ", which means under direct conditions of neutron irradiation.

In 2018, at the WWR-K reactor (Almaty, Kazakhstan), the development and creation of a modern facility to study the processes of gas release from materials of nuclear and fusion reactors was started [1]. The schematic diagram of the facility and the optimal design of the experimental irradiation device have been developed. Neutron-physical and thermophysical calculations of the irradiation device, as well as vacuum calculations of the installation for various geometries of the vacuum path have been carried out. Gas emission is recorded using a quadrupole mass spectrometer manufactured by Stanford Research System.

Due to the fact that the total length of the irradiation device is about $5 \mathrm{~m}$ and during irradiation the samples are installed in the lower part of the device, where pressure control is technically impossible, out-of-pile methodological experiments were carried out. The essence of the experiments was to determine the calibration coefficients that relate the gas flows from the area of the investigated samples to the partial pressures recorded in the area of the mass spectrometer location. The conducted methodological experiments are an important stage before the commissioning of the facility, and the results obtained are necessary for the correct interpretation of gas evolution during reactor experiments.

The work is supported by the Ministry of Education and Science of the Republic of Kazakhstan with Grant No. AP08856623.

\section{References:}

[1] Shaimerdenov A. A., Gizatulin Sh. H., Nakipov D. A., Kenzhin Ye. A., Chikhray Ye. V., Zh. A. Zaurbekova, Tolenova A. U., Nesterov E. A., Kizane G. NNC Bulletin. 2020, 1, 104-111. 


\section{Fizikālās \\ ḳīmijas sekcija}




\title{
ANALYSIS OF SORBED GASES ON SURFACE OF LITHIUM ORTHOSILICATE BASED CERAMICS WITH THERMOGRAVIMETRY AND IR SPECTROMETRY
}

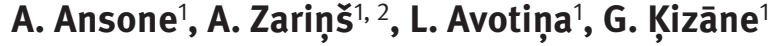 \\ ${ }^{1}$ Institute of Chemical Physics, University of Latvia, Jelgavas iela 1, Riga, Latvia \\ ${ }^{2}$ Faculty of Natural Sciences and Mathematics, Daugavpils University, Parades iela 1a, \\ Daugavpils, Latvia \\ e-mail:anna.ansone@lu.lv
}

Advanced ceramic breeder (ACB) pebbles consisting of monoclinic lithium orthosilicate $\left(\mathrm{Li}_{4} \mathrm{SiO}_{4}\right)$ as the primary phase and monoclinic lithium metatitanate $\left(\mathrm{Li}_{2} \mathrm{TiO}_{3}\right)$ as the secondary phase are accepted as a potential solid-state candidate material for the tritium breeding in future thermonuclear fusion reactors [1]. In this research, the chemical properties of the ACB pebbles and their possible analysis options were studied, including the effects of storage atmosphere. The surface chemical composition changes of the ACB pebbles were analysed over time in three different storage atmospheres using attenuated total reflection - Fourier transform infrared (ATR-FTIR) spectrometry and thermogravimetry/differential thermal analysis (TG/DTA) method coupled with FTIR spectrometry. The pressed pellets with four different nominal contents of $\mathrm{Li}_{2} \mathrm{TiO}_{3}$ were held in a normal air atmosphere (18-32 RH\%), in a dry air atmosphere (7-9 RH\%) and in a technical nitrogen atmosphere (16-29 $\mathrm{RH} \%)$ up to 63 days. The temperature during the experiment was at about $22{ }^{\circ} \mathrm{C}$, while the concentration of carbon dioxide $\left(\mathrm{CO}_{2}\right)$ in normal and dry air is assumed to be about $400 \mathrm{ppm}$.
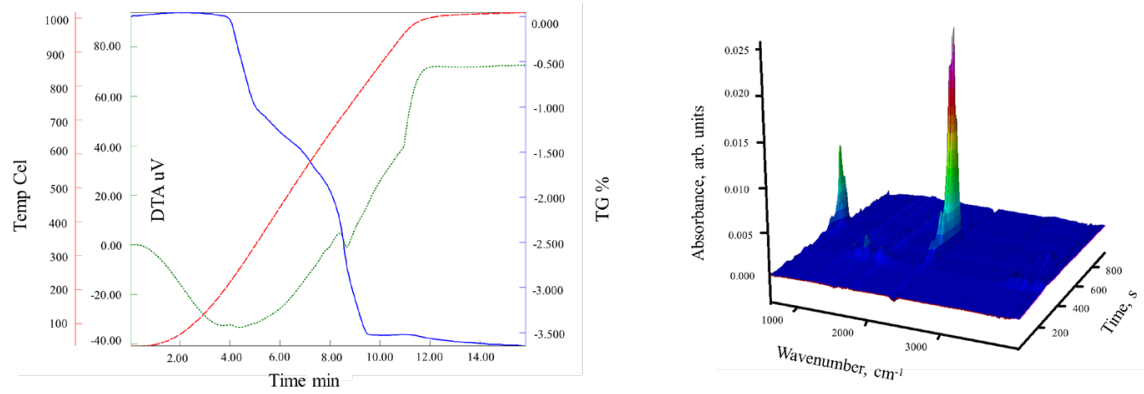

Fig. 1. The obtained TG/DTA curves (left) and FTIR spectra of evolved gaseous compounds (right) for the pressed pellets (70 $\mathrm{mol} \% \mathrm{Li}_{4} \mathrm{SiO}_{4}$ and $30 \mathrm{~mol} \% \mathrm{Li}_{2} \mathrm{TiO}_{3}$ ) after the storage in a normal air atmosphere for 63 days.

On the basis of the obtained results, it can be concluded that water $\left(\mathrm{H}_{2} \mathrm{O}\right)$ vapor and $\mathrm{CO}_{2}$ in air atmosphere have a significant effect on the surface chemical composition of $\mathrm{Li}_{4} \mathrm{SiO}_{4}$ based ceramics. For all pressed pellets, an increase in weight over time can be observed in different storage atmospheres (up to $3 \mathrm{wt} \%$ ). Over time, the chemical composition changes in the surface of $\mathrm{Li}_{4} \mathrm{SiO}_{4}$ based ceramics were detected, e.g., the formation of an amorphous lithium carbonate $\left(\mathrm{Li}_{2} \mathrm{CO}_{3}\right)$ layer. The formed $\mathrm{Li}_{2} \mathrm{CO}_{3}$ layer thermally starts to decompose at about $500{ }^{\circ} \mathrm{C}$ and thus the evolution of $\mathrm{CO}_{2}$ was detected.

\section{References:}

[1] Hernandez F. A., et al. Fusion Eng. Des. 2020, 157, 111614. 


\title{
REDUCTION OF $\mathrm{CO}_{2}$ EMISSIONS IN GREENHOUSE HEATING BY USING AIR TO AIR HEAT PUMP
}

\author{
Agris Auce $^{1 \star}$, Ivars Auce ${ }^{1}$, Indulis Horns ${ }^{1}$, Aivars Jeremuss ${ }^{2}$, \\ Semjons Ivanovs ${ }^{2}$, Mareks Drozdovs ${ }^{3}$, Ādolfs Ruciņš ${ }^{2}$ \\ ${ }^{1}$ University of Latvia, Institute of Chemical Physics, Jelgavas iela 1, Riga, Latvia \\ ${ }^{2}$ Latvia University of Life Sciences and Technology, Lielā iela 2, LV 3001 Jelgava \\ 3 SIA Rìtausma, Salas nov., Salas pag., Sala, "Saules", LV-5230 \\ *e-mail:a@aa.lv
}

Reduction of $\mathrm{CO}_{2}$ emissions in greenhouse heating were studied in an experimental greenhouse that was created by separating $34 \mathrm{~m}^{2}(\mathrm{~B}=4.15 \mathrm{~L}=8.30$ $\mathrm{H}=3.40+0.7$ ceiling $\mathrm{m}$ ) at north east corner of the main greenhouse in SIA Ritausma greenhouse facility located in Sala district in South East Latvia. Water based industrial heating system was covered by heat insulators and two $5 \mathrm{~kW}$ heat Hitachi RAC-50 air to air heat pumps were installed. Admiro tomato variety was grown in the experimental greenhouse. Heat pumps were installed inside the greenhouse at a height of $1,8 \mathrm{~m}$ and air was blown into the plant growing area.

Tomatoes were grown from February till October. Outside temperatures varied between $-7{ }^{\circ} \mathrm{C}$ and $29^{\circ} \mathrm{C}$ while inside temperature had to be kept at $20-25^{\circ} \mathrm{C}$ during day and $12-15-18{ }^{\circ} \mathrm{C}$ during night depending on plant development stage.

Small but systematic and temperature dependent deviation of air temperature from the temperature set at the control of the heating units was observed while using the built in temperature control systems in the heat pumps. The deviation was $1-3{ }^{\circ} \mathrm{C}$ below the set temperature and could be corrected by setting higher temperatures than actually required. Lower temperatures resulted in $10-30 \%$ slower growth rate as compared to control plants in the industrial production facility. The growth rate recovered after the temperatures were corrected.

Most of the time the air pumps were set in both heating and cooling mode with one of the pumps providing heating and the other one cooling to keep temperature from rising above the optimal level. The cooling had explicit negative effect on plant health and productivity during the summer season when cooling was used. Productivity decreased by $50 \%$ by weight, the size of the fruits was smaller. $20 \%$ of the plant stems died. Most probable cause was the cold air temperature, sometimes below $10{ }^{\circ} \mathrm{C}$ blown into the plant area from at the exhaust of heat pump working in cooling mode.

The energy efficiency of the air to air heat pump was compared to the gas heating system in the industrial production unit. Energy efficiency was found to be approx. 4-8 times higher resulting in 6-10 fold reduction of $\mathrm{CO}_{2}$ emissions as compared to gas heating. The exact reduction rate of the $\mathrm{CO}_{2}$ emissions depends on the $\mathrm{CO}_{2}$ emissions in electricity production since electricity can be supplied by different providers with different $\mathrm{CO}_{2}$ emission levels.

The heating costs were somewhat lower than the cost of using natural gas.

This project was supported by EAFRD - The European agricultural fund for rural development, project Nr. 17-00-A01620-000013. 


\title{
ANALYSIS OF ELECTRON IRRADIATED PROTON EXCHANGE MEMBRANES WITH INFRARED SPECTROMETRY
}

\author{
Liga Avotina', Elina Pajuste', Ingars Reinholds', Einārs Sprūğis', \\ Guntars Vaivars ${ }^{2}$ \\ ${ }^{1}$ Institute of Chemical Physics, University of Latvia, Jelgavas street 1, Riga, Latvia \\ ${ }^{2}$ Faculty of Chemistry, University of Latvia, Jelgavas street 1, Riga, Latvia \\ e-mail: liga.avotina@lu.lv
}

In last decade sulfonated poly(ether ether ketone) (SPEEK) has raised interest as potential replacement of Nafion for the development proton exchange membranes (PEM) used in the development of advanced materials including fuel cells. Their application also expands to harsh environments including exposure to ionizing radiation. Recent studies of Nafion application have indicated to need of improved performance stability under exposure to X-ray [1] and gamma [2] irradiation effect on PEM [3]. However, SPEEK be also evaluated as potential candidate of PEM under such conditions of possible ionizing radiation, their stability under, gamma, electron irradiation need to be estimated.

In this research two types of membranes, commercial Nafion 117 and SPEEK [4], were irradiated with accelerated electrons - 50, 100, 250 and $500 \mathrm{kGy}$ and analysed with means of infrared spectrometry (Bruker Vertex 70v, 400-4000 cm-1).

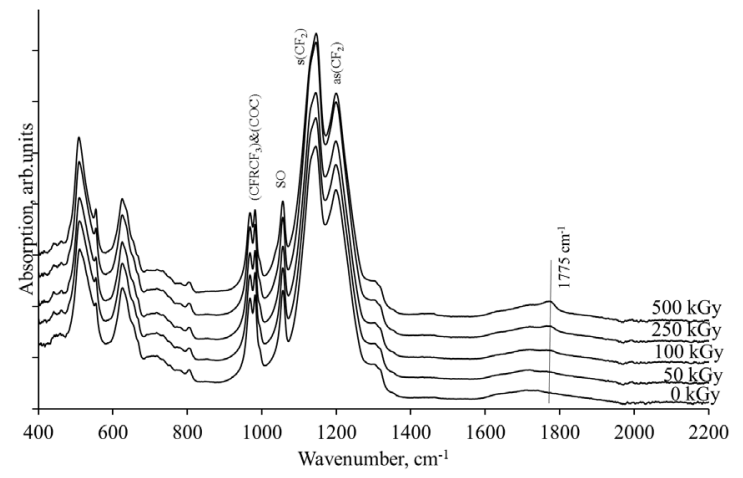

Fig. 1. Infrared spectra of non-irradiated and irradiated Nafion membranes

The preliminary results show that the structure of Nafion is stable up to absorbed doses $50 \mathrm{kGy}$. In spectra of samples irradiated with $100 \mathrm{kGy}$ an additional signal at around $1775 \mathrm{~cm}^{-1}$ occurs, that may be attributed to oxidation/degradation of $\mathrm{CF}_{2}$ groups.

The research was supported by ERDF Project No.1.1.1.1/19/137 “Graphene-based electrochemical pumping system for radioactive hydrogen isotope separation"

\section{References:}

[1] Mohamed, H. F. M., Abdel-Hady, E. E., Abdel-Hamed, M. O., Kamel, M. S. A., Journal of Solid State Electrochemistry, 2020, 24 (5), pp. 1217-1229.

[2] Almeida, S. H., \& Kawano, Y., Polymer Degradation and Stability, 1998, 62(2), 291-297.

[3] Fox, E. B., Greenway, S. D., \& Clark, E., Fusion Science and Technology, 2010, 57(2), 103-111.

[4] Vaivars, G., Krūkle-Bērziņa, K., \& Markus, M., Key Engineering Materials, 2020, 850, 138-143. 


\title{
IDENTIFICATION OF POTENTIAL PLASMEPSIN IX INHIBITORS USING HIGH-THROUGHPUT VIRTUAL SCREENING
}

\author{
Raitis Bobrovs', Iveta Kaṇepe-Lapsa', Kristaps Jaudzems ${ }^{1,2}$ \\ ${ }^{1}$ Latvian Institute of Organic Synthesis, Aizkraukles iela 21, Riga, Latvia \\ ${ }^{2}$ University of Latvia, Faculty of Chemistry, Jelgavas iela 1, Riga, Latvia \\ e-mail: raitis.bobrovs@osi.lv
}

Malaria is a deadly parasitic infection that poses an enormous threat to global health [1]. It is caused by Plasmodium parasites, with P. falciparum, being the most lethal human pathogen. During the blood stage of its life cycle, the parasite degrades human haemoglobin to produce amino acids essential for its development. This process is catalysed by the digestive vacuole aspartic proteases - plasmepsins (plms), which have been studied as targets to inhibit the growth of the parasites [2]. While most attention has so far been paid to inhibit the digestive vacuole plasmepsins (plms I, II, IV and HAP), latest knock-out studies have shown that plms I-IV are not essential for parasite survival, and inhibition of any one of them alone is not sufficient $[3,4]$. Therefore, plms V, IX and X are currently considered as main targets of the identified digestive vacuole plasmepsin inhibitors.

The target of this study - plm IX - does not have a crystal structure available, therefore a homology model based on open-flap plm II crystal structure (PDB:4Z22) was prepared to perform High Throughput Virtual Screening (HTVS) of ZINC database against plm IX. The binding stability of the 30 top-scoring HTVS fragments was evaluated using Molecular Dynamics (MD) simulations, and 20 compounds that maintained the initial docking pose in MD calculations were purchased. Their activity was tested experimentally using Fluorescence Resonance Energy Transfer (FRET) assay. Four moderately active ( IC $\left._{50} 200-100 \mu \mathrm{M}\right)$ fragments were identified using the described approach, providing promising starting point in potent antimalarial development.

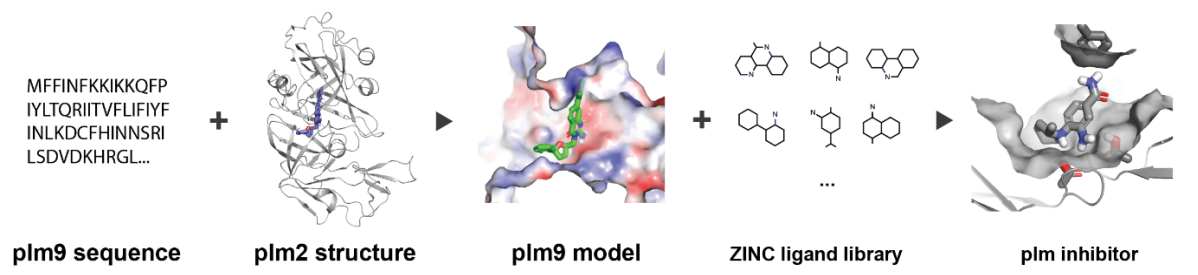

Fig. 1. Schematic plm9 inhibitor identification workflow

Acknowledgement: This research is funded by the Latvian Council of Science, project No. lzp-2020/2-0012, and ERDF project No. 1.1.1.2/VIAA/2/18/379.

\section{References:}

[1] World Health Organization. World Malaria Report 2012. 2012

[2] Gluzman, I. Y. et al. J. Clin. Invest. 1994, 93, 1602-1608.

[3] Nasamu, A. S. et al. Science. 2017, 358, 518-522.

[4] Pino, P. et al. Science. 2017, 358, 522-528. 


\title{
SYNTHESIS AND PROPERTIES OF FLEXIBLE CARBON NANOTUBE-METAL CHALCOGENIDE STRUCTURES
}

\author{
Lāsma Bugovecka', Krišjānis Buks², K. Niherush², Jana Andžāne², \\ Donāts Erts ${ }^{1,2}$ \\ ${ }^{1}$ University of Latvia, Faculty of Chemistry, Jelgavas iela 1, Riga, Latvia \\ ${ }^{2}$ Institute of Chemical Physics, University of Latvia, Jelgavas iela 1, Riga, Latvia \\ e-mail:lb14119@edu.lu.lv
}

Thermoelectric devices or generators (TEGs) are solid state devices that directly convert thermal energy into electricity [1]. TEGs are environmentally friendly and have many advantages as small size, high reliability, no pollution, usage in wide range of temperatures and high durability due to the lack of moving parts. In the field of TEGs, the development of flexible devices is an emerging trend motivated by the not linear shapes of the heated surfaces as well as the need for wearable and autonomous devices. $\mathrm{V}_{2} \mathrm{VI}_{3}$ type compounds as $\mathrm{Sb}_{2} \mathrm{Te}_{3}$ and $\mathrm{Bi}_{2} \mathrm{Se}_{3}$ are recognized as high-performance thermoelectric materials, effectively operating at near-room temperatures [2]. However, inorganic thermoelectric materials are brittle and inflexible, which hampers their application in flexible TEGs, while organic flexible thermoelectric materials (polymers) have very low efficiency. Due to this reason, the research related to the flexible TEGs is mostly focused on fabrication of organic/inorganic hybrids, for example, combining carbon nanotube networks with nanostructured inorganic thermoelectric materials, thus fabricating hybrid structures with improved thermoelectric and mechanical properties. Despite the importance of how the electrical and thermoelectric properties of the material changes with its bending, the electrical resistance and the Seebeck coefficient during the sample bending have not yet been extensively studied.

In this work, resistance and Seebeck coefficient of flexible thermoelectric films containing CNT- $\mathrm{Sb}_{2} \mathrm{Te}_{3}$ hybrid structures were studied as a function of bending radius of these films. $\mathrm{CNT}-\mathrm{Sb}_{2} \mathrm{Te}_{3}$ hybrid structures were prepared by direct deposition of $\mathrm{Sb}_{2} \mathrm{Te}_{3}$ on the CNT networks using physical vapor deposition technique and combined with the flexible non-conductive binders in different $\mathrm{CNT}: \mathrm{Sb}_{2} \mathrm{Te}_{3}$ :binder ratios. Due to the distribution gradient of the CNT- $\mathrm{Sb}_{2} \mathrm{Te}_{3}$ hybrid structures in the films, the tensile or compression of CNT-Sb ${ }_{2} \mathrm{Te}_{3}$ hybrid structures was predominant when bending them to one side, therefore the dependence of thermoelectric properties on the bending direction was also studied. Bending-dependent properties of the thermoelectric films with different $\mathrm{CNT}: \mathrm{Sb}_{2} \mathrm{Te}_{3}$ :binder ratios are compared and discussed.

\section{References:}

[1] Zhang, X.; Zhao, L. D. Thermoelectric Materials: Energy Conversion between Heat and Electricity. Journal of Materiomics. Chinese Ceramic Society June 1, 2015, pp. 92-105.

[2] Yelgel, Ö. C.; Srivastava, G. P. Thermoelectric Properties of $\mathrm{Bi}_{2} \mathrm{Se}_{3} / \mathrm{Bi}_{2} \mathrm{Te}_{3} / \mathrm{Bi}_{2} \mathrm{Se}_{3}$ and $\mathrm{Sb}_{2} \mathrm{Te}_{3} /$ $\mathrm{Bi}_{2} \mathrm{Te}_{3} / \mathrm{Sb}_{2} \mathrm{Te}_{3}$ Quantum Well Systems. Philos. Mag. 2014, 94 (18), 2072-2099.

[3] Buks, K.; Andzane, J.; Smits, K.; Zicans, J.; Bitenieks, J.; Zarins, A.; Erts, D. Growth Mechanisms and Related Thermoelectric Properties of Innovative Hybrid Networks Fabricated by Direct Deposition of $\mathrm{Bi}_{2} \mathrm{Se}_{3}$ and $\mathrm{Sb}_{2} \mathrm{Te}_{3}$ on Multiwalled Carbon Nanotubes. Mater. Today Energy 2020, 18, 100526. 


\title{
INVESTIGATION OF POSSIBILITIES TO CONTROL THE POLYMORPH OBTAINED IN CRYSTALLIZATION OF 3-HYDROXYBENZOIC ACID
}

\author{
Zane Čerpakovska' ${ }^{1}$, Kristaps Saršūns' ${ }^{1}$, Agris Bērziņš ${ }^{1}$ \\ ${ }^{1}$ University of Latvia, Faculty of Chemistry, Jelgavas iela 1, Riga, Latvia \\ e-mail: zane.cerpakovska@lu.lv
}

Polymorphism is the ability of a substance to exist in a number of crystalline modifications and can affect many aspects of drug development in pharmacy [1]. A concomitant polymorphism is an important phenomenon in which kinetics and thermodynamics are linked or it is explained how one compound can grow simultaneously to form different polymorphs [2]. The concomitant crystallization, however, is not desirable, because the obtained product is not a pure phase but a mixture in which each polymorph has its own properties [3]. Therefore, in this study we investigated the crystallization of 3-hydroxybenzoic acid (3OHBA, Figure 1), an intermediate in pharmacy, existing in a form of 2 well characterized polymorphs often reported to crystallize concomitantly [4].<smiles>O=C(O)c1cccc(O)c1</smiles>

Fig. 1. Molecular structure of 3-hydroxybenzoic acid

Crystallization using several different techniques such as evaporative, additive controlled, vapour diffusion and cooling crystallization were performed. Using the first tree of the named techniques solid products were obtained within a week or even several months, while using the last - within a couple of days. 3OHBA with the addition of PEG 6000 does not form a new crystalline phase, but it was observed that by increasing the amount of this additive increased the possibility to obtain a mixture of 3OHBA polymorphs. It was not always possible to find regularities that could explain the connection between the polymorph obtained in the crystallization and the properties of the solvent or the crystallization conditions.

\section{References:}

[1] Chen, J., Sarma, B., Evans, J. M. B., Myerson, A. S. Pharmaceutical Crystallization. Crystal Growth \& Design, 2011, 11(4), 887-895.

[2] Tang, W., Sima, A. D., Gong, J., Wang, J., Li, T. Kinetic Difference between Concomitant Polymorphism and Solvent-mediated Phase Transformation: A Case of Tolfenamic Acid. Crystal Growth \& Design, 2020, 20(3), 1779-1788.

[3] Raza, K., Kumar, P., Ratan, S., Malik, R., Arora, S. Polymorphism: The Phenomenon Affecting the Performance of Drugs. SOJ Pharmacy \& Pharmaceutical Sciences, 2014, 1(2), 10.

[4] Nordström, F. L., Rasmuson, Å. C. Polymorphism and thermodynamics of m-hydroxybenzoic acid. European Journal of Pharmaceutical Sciences, 2006, 28(5), 377-384. 


\title{
PREPARATION OF ZIRCONIUM DIOXIDE NANODISPERSIONS FROM ZIRCONIUM OXYCHLORIDE OKTAHYDRATE AND ELECTRICAL PROPERTIES OF PREPARED DISPERSIONS
}

\author{
Samanta Homiča ${ }^{1,2}$, Einārs Sprūğis ${ }^{1,2}$, Guntars Vaivars 1,2 \\ ${ }^{1}$ Institute of Solid State Physics, University of Latvia, Kengaraga iela 8, Riga, Latvia \\ ${ }^{2}$ University of Latvia, Faculty of Chemistry, Jelgavas iela 1, Riga, Latvia \\ e-mail:esprugis@cfi.lu.lv
}

Efforts in nanoparticles and nanomaterials research have been intensified in recent decades. Due to their extremely small size, these particles and materials possess unique chemical, physical and electrochemical properties which enables their use in many fields of science and industry. Zirconium dioxide $\left(\mathrm{ZrO}_{2}\right)$ nanoparticles are no exception, and its applications can include various renewable energy devices, such as fuel cells and $\mathrm{CO}_{2}$ reduction devices [1].

Several different $\mathrm{ZrO}_{2}$ dispersions were prepared using different methods of synthesis. Particle sizes and zeta potentials were determined for these dispersions at different $\mathrm{pH}$ values using Litesizer 500 particle characterization equipment.

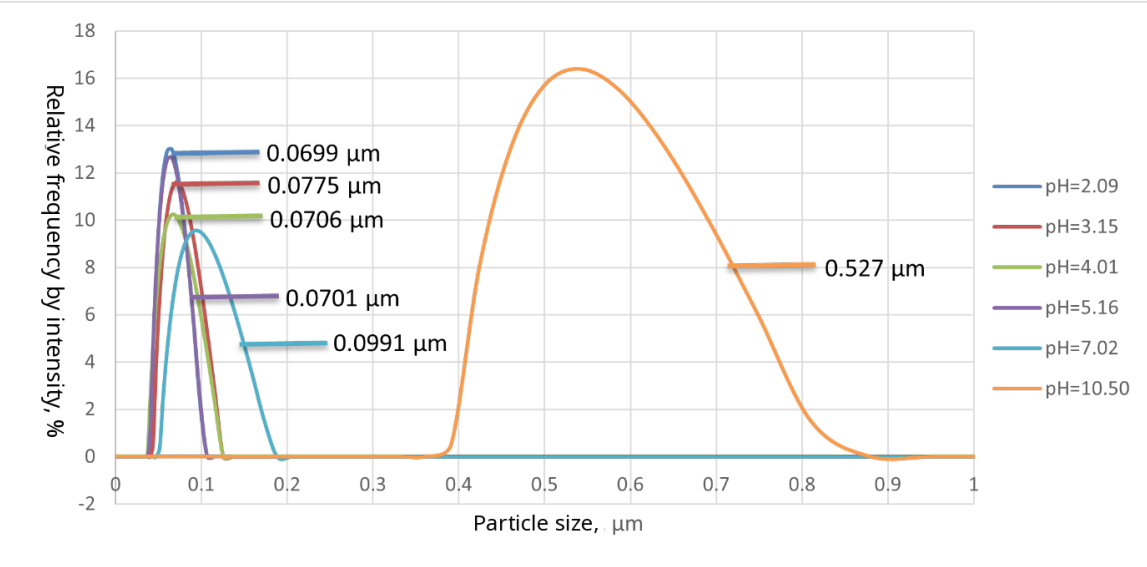

Fig. 1. $\mathrm{ZrO}_{2}$ particle size distribution at different $\mathrm{pH}$ values

The results show that each different method of synthesis yield suspension with distinctly different particle size and zeta potential, with particle sizes ranging from $70 \mathrm{~nm}$ to $700 \mathrm{~nm}$ and zeta potential from $10 \mathrm{mV}$ to $40 \mathrm{mV}$. The impact of $\mathrm{pH}$ is also noted, as higher $\mathrm{pH}$ values result in increased particle sizes and decreased zeta potential (and thus lower stability) of $\mathrm{ZrO}_{2}$ suspensions.

\section{References:}

[1] Kim, D. J.; Jo, M. J.; Nam, S. Y. A J. Ind. Eng. Chem., 2015, 21, 36-52. 


\title{
FABRICATION AND CHARACTERIZATION OF ON-CHIP SEMICONDUCTOR NANOWIRE NANOELECTROMECHANICAL SWITCHES
}

\author{
Liga Jasulaneca', Raimonds Meija', Edijs Kauranens' ${ }^{1}$, Raitis Sondors'1, \\ Jana Andzane ${ }^{1}$, Juris Prikulis ${ }^{1}$, Gunta Kunakova ${ }^{1}$, Donats Erts ${ }^{1,2}$ \\ ${ }^{1}$ Institute of Chemical Physics, University of Latvia, Jelgavas iela 1, Riga, Latvia \\ ${ }^{2}$ University of Latvia, Faculty of Chemistry, Jelgavas iela 1, Riga, Latvia \\ e-mail: liga.jasulaneca@lu.lv
}

Nanoelectromechanical (NEM) switches represent a class of devices for logic, memory and sensing applications [1]. Operation of NEM switches at cryogenic temperatures has been hindered by lack of materials with optimal combination of electrical, mechanical and thermal properties. Here we present a first-time demonstration of NEM switching down to $5 \mathrm{~K}$ using topological insulator $\mathrm{Bi}_{2} \mathrm{Se}_{3}$ nanoribbons as active elements in the switch.

We model the operation parameters and fabricate a NEM switch device on a silicon chip. The fabricated device shows distinct $\mathrm{ON}$ and OFF states, operating at $5 \mathrm{~K}$ temperature. The characterized device has switch-ON voltage from 7.8-9.2 V.
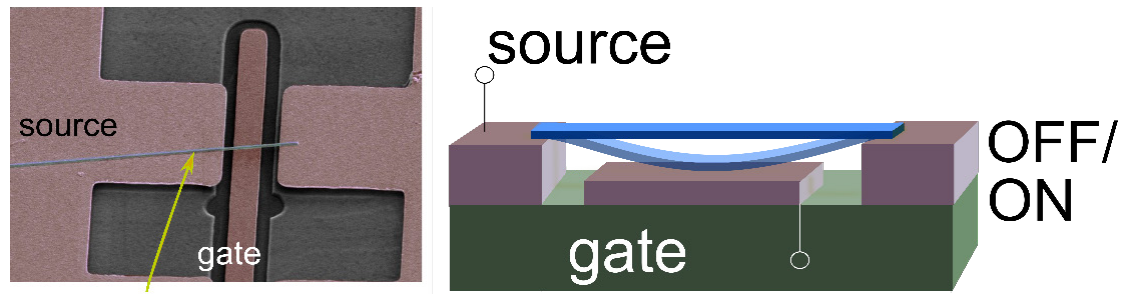

$\mathrm{Bi}_{2} \mathrm{Se}_{3}$ nanoribbon

Fig. 1. Scanning electron microscope image of a NEM switch (a) and schematics showing the operating principle of the device (b)

\section{References:}

[1] Jasulaneca L., Kosmaca J., Meija R., Andzane J., Erts D. Beilstein J. Nanotechnol. 2018 9, 271-300. 


\title{
OPTIMIZATION OF THE EFFICIENCY OF THE DISTILLATION METHOD FOR THE SEPARATION OF TRITIUM FROM BERYLLIUM-CONTAINING ACID SOLUTIONS
}

\author{
Patricija Kalnina', Elina Pajuste ${ }^{1}$, Gunta Kizane ${ }^{1}$ \\ ${ }^{1}$ Institute of Chemical Physics, University of Latvia, Jelgavas iela 1, Riga, Latvia \\ e-mail: patricijakalninja@gmail.com
}

Tritium is expected to be used for the fuel of fusion reactors [1]. In the reactor it may escape into the ventilated areas and subsequently be emitted in air effluents or it may be released as tritiated water and emitted in liquid effluents [2]. Tritium accumulates in the plasma facing materials (PFMs) beryllium and tungsten, thus reducing their service life. It needs to be separated, both from an economic and a security point of view. Therefore, it is important to estimate amounts of accumulated tritium in PFMs as well as apply and improve tritium separation methods for reuse of the materials and self-sustainability of tritium. In present research a distillation process, that is a part of tritium determination method [3] is viewed.

Solutions with the same tritium activity and different acid solutions were made in which a $1 \mathrm{~mm}$ diameter beryllium sphere was dissolved. The solutions were distilled, and their activity was measured after the distillation process. The efficiency of tritium extraction from various acid solutions was studied by distillation and activity determination using the liquid scintillation method.

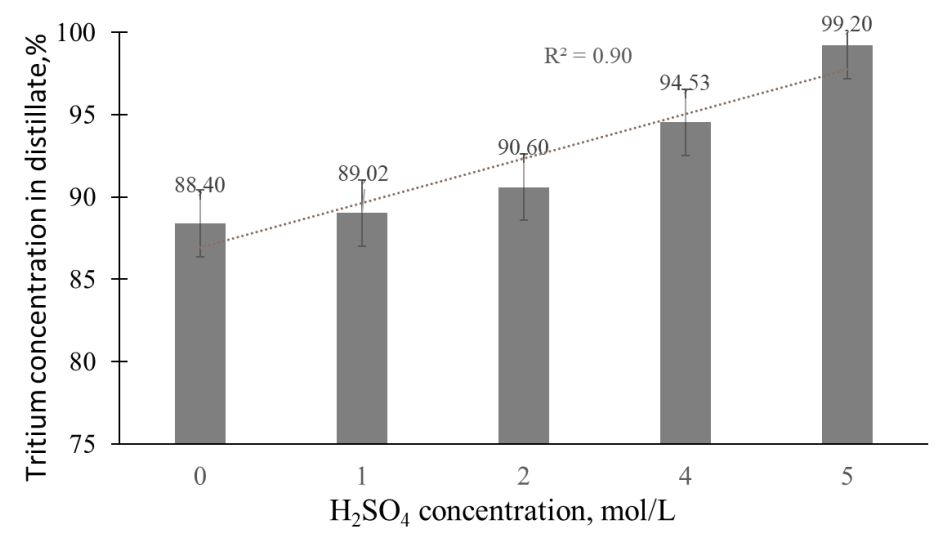

Fig. 1. Effectiveness of separating of tritium from solution, depending on molar concentrations of $\mathrm{H}_{2} \mathrm{SO}_{4}$

The separation of tritium depends on the concentration of tritium in water - the lowest distribution effectiveness is for a solution of $1 \mathrm{M}$ sulphuric acid of $89.02 \%$ and the highest for a solution of $5 \mathrm{M}$ sulphuric acid of $99.20 \%$.

\section{References:}

[1] Fukada, S.; Miho, Y.; Katayama, K. Fusion Engineering and Design 2018, 133, 64-69.

[2] Văsaru, G. Tritium Isotope Separation; CRC Press: Boca Raton, 1993.

[3] Pajuste, E.; Kizane, G.; Avotina, L.; Teimane, A. S.; Lescinskis, A.; Vonda, K.; JET Contributors. Nucl. Fusion 2019, 59. 


\section{CHEMICAL COMPOSITION OF MALUS DOMESTICA LEAVES}

\section{Ksenija Kokina ${ }^{1}$, Valda Valkovska ${ }^{1}$}

${ }^{1}$ University of Latvia, Faculty of Chemistry, Jelgavas iela 1, Riga, Latvia e-mail: ksenijakokina@inbox.lv

The apple tree (Malus Domestica) is one of the most widely cultivated fruit trees. The chemical composition of apples has been extensively studied, however other parts of the plant have been less investigated. The leaves are valuable source of quercetin derivatives, dihydrochalcones and volatile organic compounds [1]. In addition, mentioned as a traditional dye plant [2]. Biologically active compounds from apple leaves could use in cosmetic industry and production of dietary supplements.

The study will present results of 22 volatile organic compounds (VOCs) and 18 flavonoids in extracts of Malus Domestica leaves. Among the VOCs identified, alcohols ( $\beta$-linalool, dodecanol), ketones (cyclohexanone, damascenone), ethers (1-metoxy-2-propylacetate) and terpenes (terpheniol) were found in several samples using GC-MS analysis, databases and literature.

The phytochemical screening of the extracts using UHPLC-DAD-MS showed the presence of compounds from different polyphenolic groups: dihydrochalcones (phloretin, phlorizin), flavan-3-ols (dimeric B type proanthocyanidin, catechin, epicatechin, gallocatehin, epigallocatechin), flavanols (hyperoside, rutin, quercetrin), phenolic acids and other compounds. Identification was based on accurate masses of their protonated $[\mathrm{M}+\mathrm{H}]^{+}$ions, mass spectra, UV-visible absorption spectra, in-house database and literature [3].

\section{References:}

[1] Liaudanskas M., Viškelis P., Raudonis R., Kiviklys D., Uselis N., Janulis V. The Scientific World Journal. 2014, 11, 1-10.

[2] Eser F., Tutak M., Onal A., Meral B. Journal of Natural Fibers. 2016, 3, 289-298.

[3] Valkovska V., Orola L. Book of abstracts: Materials Science and Applied Chemistry 2020, Riga Technical University, Riga, 2020, 81. 


\title{
HEXAMORPHISM OF DANTROLENE: INSIGHT INTO THE CRYSTAL STRUCTURES, STABILITY, AND PHASE TRANSFORMATIONS
}

\author{
Artis Kons', Anatoly Mishnev², Timur A. Mukhametzyanov³, \\ Alexey V. Buzyurov ${ }^{3}$, Semen E. Lapuk ${ }^{3}$, Agris Bērziṇš ${ }^{1}$ \\ ${ }^{1}$ University of Latvia, Faculty of Chemistry, Jelgavas iela 1, Riga, Latvia \\ ${ }^{2}$ Latvian Institute of Organic Synthesis, Aizkraukles iela 21, Riga, Latvia \\ ${ }^{3}$ Department of Physical Chemistry, Kazan Federal University, Kremlevskaya str. 18, \\ Kazan, Russia \\ e-mail:artis.kons@lu.lv
}

Polymorphism is the ability of a compound to exist in a number of crystalline forms. This phenomenon is highly important in the manufacturing of pharmaceuticals, since properties such as solubility, dissolution rate, melting point, density, tabletability, etc. of different polymorphs may differ.

Dantrolene (1-[[5-(4-nitrophenyl)furan-2-yl]methylideneamino]imidazolidine-2,4-dione) is a skeletal muscle relaxant that depresses the intrinsic mechanisms of excitation-contraction coupling. It reduces the spasms, cramping, and muscle stiffness caused by certain medical problems, such as disseminated sclerosis, a stroke, or an injured spine [1]. Dantrolene represents yet another interesting example of abundant molecular crystal polymorphism existing in at least six different neat polymorphs, three of which can be obtained via crystallization (I-III) and an additional three (IV-VI) via solid-state dehydration from three different monohydrates (MH-I-MH-III). The reasons for polymorph formation were rationalized by analyzing the crystal structures of the polymorphs and hydrates used in their preparation. The thermodynamic relations among the polymorphs were established from calorimetric data, solubility measurements, and lattice energy calculations.

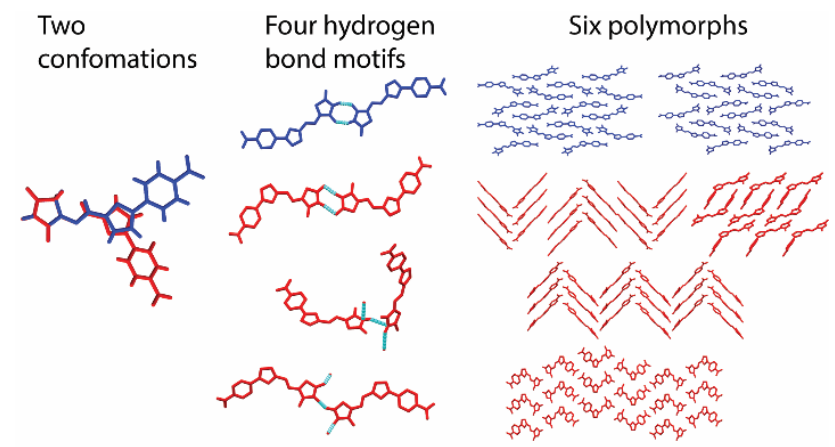

Fig. 1. Comparison of conformations, H-bond motifs and molecular packing of dantrolene polymorphs

\section{References:}

[1] Krause, T., Gerbershagen, M. U., Fiege, M., Weißhorn, R., Wappler, F. Anaesthesia 2004, 59, 364-373. 


\section{INCONEL-718 ALLOY ELECTROCHEMICAL POLISHING}

\section{E. Lagzdina', 2, E. Pajuste ${ }^{1,2}$, G. Kizane', A. Lescinskis' ${ }^{1}$}

EUROfusion Consortium, JET, Culham Science Centre, OXI14 3DB, Abingdon, UK

${ }^{1}$ Institute of Chemical Physics, University of Latvia, 1 Jelgavas street, Riga, Latvia

${ }^{2}$ University of Latvia, Faculty of Chemistry, Jelgavas iela 1, Riga, Latvia

e-mail: elzaberga29@gmail.com

Metals and their alloys are an integral part of today. Their development and research dates back to the Bronze Age, when man learned that combining 2 metals together could create something stronger and better. The development of metal alloys is continuous. One of the newest and least studied metal superalloys is Inconel-718. Inconel-718 is of great importance in various industries and nuclear technology due to its outstanding chemical and physical properties.

The use of Inconel-718 is also planned in the construction of future fusion reactors. Its application is currently being tested in an experimental fusion reactor, the Joint Eurpean Toruss (JET).

One of the important aspects of fusion reactor safety is fusion fuel, radioactive hydrogen - tritium, diffusion and accumulation in reactor materials. Until now, the Institute of Chemical Physics of the University of Latvia has developed methods for estimating the total amount and volume distribution of tritium in pure metals, beryllium and tungsten, which are based on simultaneous gradual dissolution of the material and measurements of released tritium. The aim of this work is to develop a method for controlled electrochemical dissolution of Inconel-718 alloy with further application for tritium determination after operation in fusion facilities.

In order to achieve the goal of the work, the following tasks were set:

1. Find an optimal solvent that does not emit corrosive gases during the electrochemical dissolution process.

2. Find the optimal solvent concentration at which the dissolution process occurs most rapidly

3. Evaluate the surface roughness of Inconela-718 after reconstitution by SEM

4. Evaluate the uniformity of dissolution of Inconel-718-forming metals based on their concentration in solution and alloy.

According to the results obtained in order to electrochemically polish Inconel-718 alloy, it is necessary to use $4 \mathrm{M}-6 \mathrm{M}$ sulfuric acid solution as electrolyte and apply and $3 \mathrm{~V}$ voltage. After 15 minutes of electropolishing, the appearance of the Inconel-718 material at the anode has changed and weight has decreased. SEM analysis confirmed that the surface roughness has decreased after polishing.

Chemical composition for all used solutions was performed to confirm that dissolution has took place for all constituting metals similarly. Results showed that the amount of ions in $4 \mathrm{M} \mathrm{H}_{2} \mathrm{SO}_{4}$ varies greatly. $\mathrm{Ni}^{2+}$ ions in $4 \mathrm{M}$ sulfuric acid solution are present in higher concentrations than in $6 \mathrm{M}$ sulfuric acid solution, the same applies to $\mathrm{Cu}^{2+}, \mathrm{Fe}^{3+}$, etc. It means that dissolution process in $4 \mathrm{M}$ acid was more efficient. 


\title{
FORMATION OF SOLID SOLUTION IN XANTHONE DERIVATIVE SYSTEMS EXHIBITING LUMINESCENCE PROPERTIES
}

\author{
Kristaps Saršūns ${ }^{1 *}$, Aleksejs Karziṇins' ${ }^{1}$, Kaspars Leduskrasts², \\ Agris Bērziņš ${ }^{1}$, Toms Rekis ${ }^{1}$ \\ ${ }^{1}$ Faculty of Chemistry, University of Latvia, Jelgavas iela 1, Riga, Latvia \\ ${ }^{2}$ Latvian Institute of Organic Synthesis, Aizkraukles iela 21, Riga, Latvia \\ e-mail: kristaps.sarsuns@lu.lv
}

Solid solutions (SS) are multicomponent phases for which the component ratios can be varied in continuum. These phases consist of different molecular constituents randomly occupying crystallographic sites [1]. The changes in composition are often accompanied by a continuous change in some physical and/or chemical properties (e.g., density, solubility, stability, and more complex properties such as non-linear optical properties, solid-state luminescence and phosphorescence properties) $[1,2]$.

Several xanthone (XANT) derivatives (Figure 1) were selected as model compounds because of their physico-chemical properties and chemically similar structures, in which the different atom (X and $\mathrm{R}$ ) may not significantly affect the dominant intermolecular interactions [2].

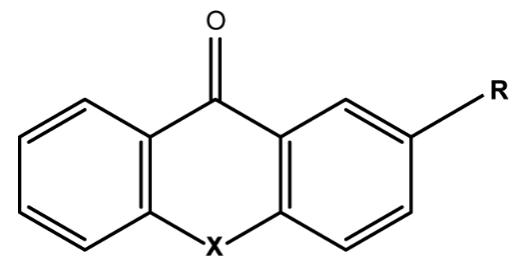

$\mathbf{X}=\mathbf{O}($ XANT) or $\mathbf{S}$ (TXANT)
$\mathbf{R}=\mathbf{H}$ (XANT and TXANT),
$\mathbf{C l}$ (TXANT-Cl) or I (TXANT-I)

Figure 1. Molecular structure of xanthone derivatives.

The binary systems of xanthone derivatives (XANT : TXANT and TXANT-Cl: TXANT-I) have been explored showing that four different solid solutions (formed based on parent structures of xanthone derivatives, respectively) can be formed. The obtained crystalline phases were characterized using powder X-ray diffraction (PXRD) and differential scanning calorimetry (DSC) methods in order to construct respective phase diagrams. Furthermore, photoluminescence spectra of all crystalline phases in powder form were recorded to see how they change with respect to those of the pure substances known from the literature [3].

This work has been supported by the Latvian Council of Science, project "Crystal engineering of pharmaceutical multicomponent phases for more efficient crystalline phase design", project No. lzp-2018/1-0312 and University of Latvia foundation through "Mikrotikls" doctoral scholarship in the field of natural and medical sciences.

\section{References:}

[1] Lusi, M. Crystal Growth \& Design, 2018, 18(6), 3704-3712.

[2] Saršūns, K., Bērziňš, A., Rekis, T. Crystal Growth \& Design, 2020, 20(12), 7997-8004.

[3] Wen, Y., Liu, H., Zhang, S., Gao, Y., Yan, Y., Yang, B. J. Mater. Chem. C, 2019, 7, 12502-12508. 


\title{
SCREENING OF CRYSTALLIZATION ADDITIVES FOR POLYMORPH CONTROL OF 2,6-DIMETHOXYBENZOIC ACID
}

\author{
Aina Semjonova, Agris Bērziņš \\ University of Latvia, Faculty of Chemistry, Jelgavas iela 1, Riga, Latvia \\ e-mail:ainasemjonova@gmail.com
}

Control of polymorphic forms is a mandatory requirement for active pharmaceutical substances. One of the possible methods to prevent concomitant crystallization of polymorphic forms is use of crystallization additives or templates. $[1,2]$

In this study 2,6-dimetoxybenzoic acid (2,6MeOBA) was used as a model substance to investigate this crystallization control approach. 2,6MeOBA exists as 3 polymorphs. Form I contains hydrogen bonded chains (catemer synthon). Forms II and III are thermodynamically unstable at room temperature and contain carboxylic acid homodimers. Form I form has carboxylic group in anticonformation, whereas forms II and III are syn-conformation (see Figure 1). [3-6]

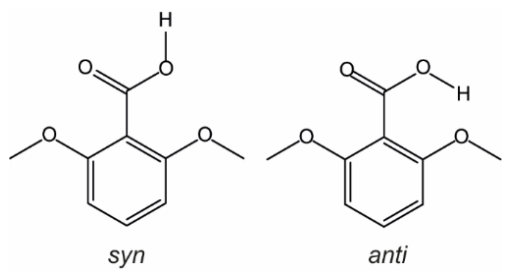

Fig. 1. Molecular structure of 2,6MeOBA showing both conformations of carboxylic group

Firstly, 2,6MeOBA was crystallized under different conditions by performing evaporation and cooling crystallization from different solvents. For evaporation crystallization various temperatures were used. For cooling crystallization different cooling rates were used. Secondly, after evaluation of the polymorph outcome in crystallization from pure solvents, few solvents were selected for additive screening. Surfactants, polymers and different molecular compounds with divergent intermolecular interaction possibilities were used as additives. Solid forms obtained in crystallization were characterized with powder X-ray diffraction.

In most cases the polymorphic outcome of the crystallization in presence of additives coincides with that obtained in crystallization from pure solvent. Nevertheless, some additives facilitated formation of form I, whereas others - form III. Moreover, few additives (glycine, BIS-TRIS) favored formation of form II, which has never been crystallized from pure solvents.

Hydroxypropyl cellulose, 2,6-dimethoxyphenylboronic acid and polyethylene glycol showed potential to favor formation of form III by crystallizing from water.

\section{References:}

[1] Simone, E.; Steele, G.; Nagy, Z. K. CrystEngComm 2015, 17 (48), 9370-9379.

[2] Kulkarni, S. A.; Weber, C. C.; Myerson, A. S.; Host, J. H. Ter. Langmuir, 2014, 30 (41), $12368-$ 12375.

[3] Portalone, G. Acta Cryst. E. 2009, E65, o327-o328.

[4] Portalone, G. Acta Cryst. E. 2011, E67, o3394-03395.

[5] Pal, R.; Jelsch, C.; Malaspina, L. A.; Edwards, A. J.; Murshed, M. M.; Grabowsky, S. J. Mol. Struct. 2020, 1221, 128721.

[6] Portalone, G. Acta Cryst. E. 2020, E76, 1823-1826. 


\title{
EFFECTS OF RADIATION ON CMS MTD BTL COMPONENTS AND BINDING MATERIALS
}

\author{
Toms E. Šusts' ${ }^{1}$ Elīna Pajuste ${ }^{1}$, Gunta Ķizāne ${ }^{1}$ \\ ${ }^{1}$ Institute of Chemical Physics, Laboratory of Radiation Chemistry of Solids \\ University of Latvia, Jelgavas iela 1, Riga, Latvia \\ e-mail: tomselvijs@gmail.com
}

From 2024 to 2026 CERN will upgrade the Compact Muon Solenoid (CMS) experiment of their High Luminosity Large Hadron Collider (HL-LHC) during a long shutdown. The upgrade aims to improve the resolution of detector systems, allowing to conduct such experiments as separating the trajectories and energy deposits of particles produced in hard proton collisions and differentiating them form the more prevalent softer collisions [1].

An important factor that reduces detector resolution is pileup. Because of this an essential part of the upgrade is the Minimum Ionising Particle (MIP) Timing Detector's barrel timing layer (BTL), consisting of Cerium doped Lutetium (LYSO:Ce) crystals coupled to silicon photomultipliers (SiPMs). With an estimated resolution of 30-40ps they will reduce the effects of high levels of pileup and allow to determine the time of flight of MIPs more precisely. This will grant the opportunity to resolve collisions that occur close together, but at different times [2].

After the upgrade installation the HL-LHC is planned to be operational without long shutdowns until 2029, so it is of paramount importance to determine the durability of detector components and how different types of radiation and temperature fluctuations affect them. Especially when taking into account that some detectors are predicted to be subjected to fluences as high as $10^{16}$ particles/ $\mathrm{cm}^{2}$ and temperature fluctuations from -30 to $400{ }^{\circ} \mathrm{C}$ [3].

In this presentation the planed future work on determining the effects of radiation and temperature fluctuations on the detector components is discussed.

\section{References:}

[1] New paradigms for the CMS phase-2 upgrade. https://cms.cern/news/new-paradigms-cmsphase-2-upgrades (accessed 15.01.2021).

[2] Malberti M., JINST, 2020, 15 C04014.

[3] Technical Proposal for the Phase-II Upgrade of the CMS Detector. http://cds.cern.ch/ record/2020886/files/LHCC-P-008.pdf (accessed 15.01.2021). 


\title{
BEHAVIOR OF DIHYDROXYBENZOIC ACID MOLECULES IN SOLUTIONS DETERMINED USING SPECTROSCOPIC METHODS AND MOLECULAR DYNAMICS SIMULATIONS, AND THE POSIIBLE EFFECT OF DISPARITIES ON THEIR PROPENSITY TO FORM SOLID PHASES
}

\author{
Aija Trimdale, Agris Bērziň̨̌ \\ University of Latvia Faculty of Chemistry, Jelgavas iela 1, Riga, Latvia \\ e-mail:aija.trimdale@lu.lv
}

Dihydroxybenzoic acids (diOHBA) are small organic molecules. The arrangement of the hydroxyl groups in the benzene ring has a significant effect on their propensity to form different solid phases when crystallized from solution. This allows to categorize diOHBA into four distinct groups based on the solid phases obtainable from solution. To investigate the behaviour of diOHBA molecules in solution and rationalize potential disparities that could lead to the mentioned diversity of the obtainable crystalline phases, FT-IR and NMR spectroscopic studies as well as molecular dynamic (MD) simulations were employed $[1,2]$. Acetonitrile (ACN), tetrahydrofuran (THF) and 2-propanol (IPA) were used as solvents.

Classical carboxylic acid homodimer is a building block prominently present in almost all crystal structures of both solvated and non-solvated crystalline phases. However, by analysing both FT-IR spectra and molecule trajectories obtained from MD simulations the presence of this dimer was not prominent in any of the solutions. This allows to conclude that its formation in the solid structures is not caused by its presence in the solution state.

Although both spectroscopic methods and MD simulations indicated that the majority of the molecules in the solution exist as monomers, self-association of diOHBA involving carboxylic group could also be observed, more particularly, the formation of various species containing hydrogen bond between the carboxyl group and phenolic hydroxyl group. Moreover, associates containing hydrogen bond between carboxyl groups or hydroxyl groups, molecule clusters, and stacked molecules in various degrees could also be observed depending on the examined diOHBA. Additionally, the extent of hydrogen bond formation with solvent molecules and the mean lifetime of solute-solvent associates formed by diOHBA and 2-propanol were also investigated.

\section{References:}

[1] Hansen P. E., Spanget-Larsen. NMR and IR Investigations of Strong Intramolecular Hydrogen Bonds. Molecules 2017, 22, 552.

[2] Bobrovs, R.; Drunka, L.; Auzins, A. A.; Jaudzems, K.; Salvalaglio, M. On the PolymorphSelective Role of Hydrogen Bonding and $\pi-\pi$ Stacking in Para-Aminobenzoic Acid Solutions. Cryst. Growth Des. 2021, 21, 436-448. 


\title{
MODIFICATION OF BENTONITE CLAY WITH ZWITTERIONS FOR APPLICATION IN SPEEK COMPOSITE MEMBRANES
}

\author{
Anna Trubača-Boginska', Rūta Ādiṇa', Anda Prikšāne', \\ Guntars Vaivars' ${ }^{1}$, Jānis Švirksts ${ }^{1}$ \\ ${ }^{1}$ University of Latvia, Faculty of Chemistry, Jelgavas 1, Riga, Latvia, LV-1004 \\ e-mail: anna.trubaca-boginska@lu.lv
}

With the rapid increase in environmental pollution (particular $\mathrm{CO}_{2}$ emission), new, renewable, and efficient energy sources are being sought to reduce the use of fossil fuels for energy production. One of the most attractive solutions would be to use polymer electrolyte fuel cells (PEFC), because it is possible to obtain high energy content with low environmental impact. However, their costs are often the determining factor for fuel cell application in transportation, portable and stationary power generation in industrial volumes, because the end products (cars, heat and power systems for residential buildings) are inadequately expensive for the average consumer. This means that, the main challenge is to reduce the cost of PEFC (without decreasing the performance) let it be competitive with fossil fuels.

The most common way to reduce PEFC costs is to replace commercial Nafion $\odot$ (or other) polymer electrolyte membranes with cheaper analogues, such as sulfonated poly(ether ether ketone) (SPEEK). SPEEK has high chemical, thermal and mechanical stability at a low degree of sulfonation (DS), as well as low proton conductivity. On the other hand, at a high DS, SPEEK proton conductivity is high and comparable to commercial membranes, but the mechanical properties are significantly worse. Therefore, for SPEEK, the main challenge is to find the best technical solution that would increase the proton conductivity of the polymer without compromising its chemical and mechanical properties.

In this study, the change of SPEEK properties by adding zwitterion-modified bentonite clay additives was observed. The main ideas of the study were that: 1) due to the modification of bentonite clay with zwitterions, the surface of the clay from hydrophilic would become hydrophobic, thus improving the dispersion of the additive in the polymer; 2 ) the inorganic phase of the additive would improve the chemical and mechanical properties; 3) sulfonate groups would increase the total number of proton-conducting functional groups in the composite, leading to higher proton conductivity.

Accordingly, in this study bentonite clay was modified by cation exchange reaction with the following zwitterion-containing compounds - 3-methyl-1(3-sulfopropyl)imidazolium hydrogen sulfate, 1-sulfopropyl pyridinium hydrogen sulfate and $\mathrm{N}, \mathrm{N}^{\prime}$-bis(3-sulfopropyl)- $\mathrm{N}, \mathrm{N}, \mathrm{N}^{\prime}, \mathrm{N}^{\prime}$-tetramethylethylene diammonium hydrogen sulfate. Zwitterion adsorption on bentonite clay was studied by X-ray diffractometry, X-ray fluorescence spectrometry, differential scanning calorimetry and thermogravimetric analysis. The properties of SPEEK/zwitterion-bentonite clay composite membranes were characterized by proton conductivity, water uptake and mechanical strength.

This work was supported by University of Latvia, project "Nano, Quantum Technologies, and Innovative Materials for Economics". 


\section{CHARACTERIZATION OF PIGMENTS FROM RUMEX CONFERTUS ROOT FOR WOOL DYEING}

\section{Valda Valkovska', Liāna Orola ${ }^{1}$}

${ }^{1}$ University of Latvia, Faculty of Chemistry, Jelgavas iela 1, Riga, Latvia

e-mail:valda.valkovska@lu.lv

Natural dyeing of textiles is a traditional cultural heritage of Latvia. Craftsmen and peasants were used mainly local plants to obtain dyes until the mid-nineteenth century. Plants and mordants provide a wide colour range of flavonoids and anthraquinones from yellow to brown, reddish and green. According to written sources and recipes, the most commonly used mordant for wool dyeing was an aluminium potassium sulfate [1].

Rumex confertus is one of an invasive plant species that infesting meadows throughout the Central Europe. Rumex species have used in food, traditional medicine and natural dyeing. According to the recipes and the descriptions sorrel give a different shade of colours: green, red and grey [2]. The species are rich in flavonoids (vitexin, orientin, rutin, astragalin, quercetin, kaempferol) and anthraquinones (chrysophanol, emodin, physicon, rhein), particularly in the roots [3]. The anthraquinone chromogen provide all the significant natural red dyes.

This study will present results of the chemical analysis of mass spectrometry, evaluating the content of pigments in $R$. confertus dyeing solution and in dyed woolen yarn nowadays. The yarn was dyed with fresh root of $R$. confertus. Before dyeing the yarn was treated with potassium aluminium sulphate mordant. Dyestuffs from the yarn were extracted in compliance with the method of hydrolysis described by Wouters and Verhecken (1989) with some modifications [4]. The extracts were analysed by ultra performance liquid chromatography coupled with diode array detector and mass spectrometry (UPLC-DAD-MS) for identification of the pigments.

\section{References:}

[1] Cardon D. Natural Dyes: Sources, Tradition, Technology and Science, Archetype, London, 2007.

[2] Madre I. Krāsošana ar augu krāsvielām [Dyeing with Plant Dyes], Avots, Rīga, 1990.

[3] Saleh N. A. M. Biochem. Syst. Ecol. 1993, 21, 301-303.

[4] Graaff J. H. H., Roelofs W. G. T., Bommel M. R. The Colourful Past: Origins, Chemistry and Identification of Natural Dyestuffs, Archetype Publications, London, 2004.

[5] Wouters J., Verhecken A. Studies in Conservation. 1989, 4, 189-200. 


\section{Organiskās k̦īmijas sekcija}




\section{TOWARDS DYNAMIC KINETIC RESOLUTION OF AMINES}

\section{Linda Luīze Barbare" ${ }^{1,2 *}$}

${ }^{1}$ University of Latvia, Faculty of Chemistry, Jelgavas iela 1, Riga, Latvia

${ }^{2}$ Latvian Institute of Organic Synthesis, Aizkraukles iela 21, Riga, Latvia

e-mail: linda.barbare@gmail.com

Chiral amines have found widespread application in asymmetric synthesis and are prevalent, essential parts of many drugs [1]. Enantiopure amines can be obtained through direct synthesis for example using enantioselective imine reduction or through a separation of enantiomers by chiral column chromatography or kinetic resolution (KR). Separation of enantiomers using chiral stationary phase column chromatography or KR is especially attractive as it can be performed on easily accessible racemic amines. However, these processes can produce a maximum $50 \%$ yield of an enantiopure amine. The limited yield can be overcome by employing a dynamic kinetic resolution (DKR).

The DKR consists of two-tandem process - the KR of racemic amine and racemization of the slower reacting amine that allows for recycling of undesired enantiomer [3]. As a result, the DKR allows for the conversion of racemic amine to a single enantiomer. However, the success of the DKR reaction depends on the proper balancing of the rates of the two-paired catalytic processes. To this end, a transition metal catalysis is employed for racemization of the slower reacting amine and enantioselective acylation is usually achieved using enzymatic catalysis [4]. To best of our knowledge, there are no examples of non-enzymatic DKR of amines. To expand application of the DKR, we strive to develop a nonenzymatic DKR of amines employing chiral Lewis base-catalyzed enantioselective acylation of amines in tandem with photocatalyzed racemization of the slower reacting enantiomer of the amine.

Supervisor: Dr. chem. Artis Kinēns

Acknowledgements: This work was supported by ERDF (Post-Doc Latvia) project No. 1.1.1.2/VIAA/3/19/589.

\section{References:}

[1] Grogan, G. Curr. Opin. Chem. Biol. 2018, 43, 15-22.

[2] Keith, J. M.; Larrow, J. F.; Jacobsen, E. N. Adv. Synth. Catal. 2001, 343, 5-26.

[3] Lee, J. H.; Han, K.; Kim, M.-J.; Park, J. Eur. J. Org. Chem. 2010, 2010, 999-1015.

[4] Verho, O.; Bäckvall, J. E. J. Am. Chem. Soc. 2015, 137, 3996-4009. 


\section{SYNTHESIS AND PHOTOPHYSICAL PROPERTIES OF TRIAZOLYL PURINES}

\section{Aleksejs Burcevs ${ }^{\star}$, Armands Sebris, Andris Jeminejs}

Faculty of Materials Science and Applied Chemistry, Riga Technical University, P. Valdena str. 3, Riga, Latvia

e-mail:aleksejs.burcevs@rtu.lv

Purine-triazole conjugates belong to the push-pull systems and possess fluorescent properties which can be potentially used in OLED technology and in cell imaging $[1,2]$. Recently, we found that our 2,6-bis-triazolyl purine derivatives can be used as ratiometric chemical sensors [3].

In this study, we synthesized 6- or 2,6-bis(1H-1,2,3-triazol-4-yl)-9H-purine and 6- or 2,6-bis(1H-1,2,3-triazol-1-yl)-9H-purine derivatives 1-4, using the sequence of Mitsunobu, Sonogashira, azide-alkyne cycloaddition and $S_{N} A r$ reactions in different order. In addition, analogues 1 and $\mathbf{2}$ possess enhanced stability due to $\mathrm{C}-\mathrm{C}$ bond connection of 1,2,3-triazole to the purine ring, thus this triazole cannot act as a leaving group. Further, photophysical properties of obtained compounds have been studied. Quantum yields reach up to $81 \%$ in DCM.
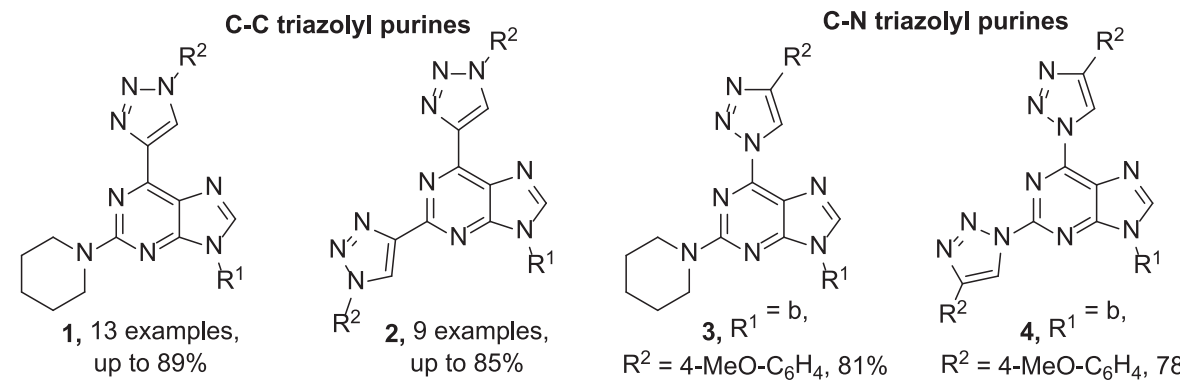

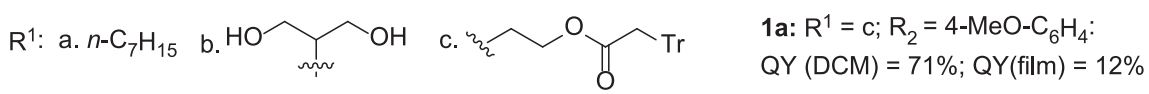

Supervisors: Dr. chem. M. Turks, Dr. chem. I. Novosjolova

\section{References:}

[1] Šišuliins, A.; Bucevičius, J.; Tseng, Y.; Novosjolova, I.; Traskovskis, K.; Bizdēna, Ē.; Chang, H.; Tumkevičius, S.; Turks, M. Beilstein J. Org. Chem. 2019, 15, 474-489.

[2] Traskovskis, K.; Sebris, A.; Novosjolova, I.; Turks, M.; Guzauskas, M.; Volyniuk, D.; Bezvikonnyi, O.; Grazulevicius, J.; Mishnev, A.; Grzibovskis, R.; Vembris, A. J. Mater. Chem. C, 2021, submitted TC-ART-10-2020-005099.R1.

[3] Jovaisaite, J.; Cīrule, D.; Jeminejs, A.; Novosjolova, I.; Turks, M.; Baronas, P.; Komskis, R.; Tumkevicius, S.; Jonusauskas, G.; Jursenas, S. Phys. Chem. Chem. Phys. 2020, 22, 2650226508. 


\section{COBALT-CATALYZED C(sp²)-H BOND CARBONYLATION}

\section{Aleksandrs Čižikovs*}

Latvian Institute of Organic Synthesis, Aizkraukles street 21, LV-1006, Riga, Latvia

e-mail: aleksandrs.cizikovs@osi.lv

Over past few decades the interest towards $\mathrm{C}-\mathrm{H}$ bond activation and functionalization has increased. Majority of the results have been achieved using third row transition metals such as $\mathrm{Pd}, \mathrm{Rh}$ and $\mathrm{Ru}$. [1] Unfortunately, these transition metals are rather expensive and toxic. [1] Cobalt being cheaper and less toxic element than noble metals has emerged as an attractive alternative to already existing precious metal catalysts. [2]

Herein we report Co-catalyzed $\mathrm{C}-\mathrm{H}$ carbonylation of phenylalanine derivatives 1 using picolinamide as a traceless directing group. During the experiments we found out that phenylalanine derivatives 1 reaction with $\mathrm{CO}$ gas leads to formation of 1,2-dihydroisoquinoline derivative 3 in excellent yields.

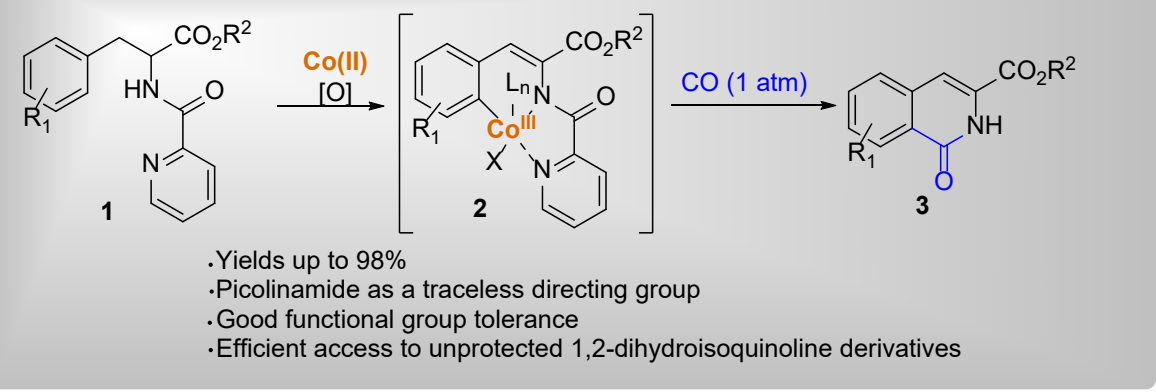

Supervisors: Dr. Chem. Liene Grigorjeva, M. Sc. Ing. Lūkass Lukašēvics

\section{References:}

[1] Gandeepan, P.; Muller, T.; Zell, D.; Cera, G.; Warratz, S.; Ackermann, L. Chem. Rev., 2019, 119 (4), 2192.

[2] Silva, J. J. R. F.; Williams, R. J. P. The Biological Chemistry of the Elements: The Inorganic Chemistry of Life; 2nd ed.; Oxford University Press: Oxford, U.K., 2001. 


\section{A MECHANISTICAL STUDY OF LEWIS BASE CATALYZED CYANOHYDRIN SYNTHESIS}

\section{Artūrs Raimonds Feldmanis ${ }^{1,2}$, Oto Filipsons ${ }^{1,2}$}

${ }^{1}$ University of Latvia, Department of Chemistry, Jelgavas 1, LV-1004 Riga, Latvia

${ }^{2}$ Latvian Institute of Organic Synthesis, Aizkraukles 21, Riga, LV-1006, Latvia e-mail:arturs.raimonds.feldmanis@osi.lv

Enantiopure cyanohydrins are valuable building blocks in organic chemistry. Both functional groups of cyanohydrins can be easily modified giving access to many valuable organic compounds.

We have developed a Lewis base catalyzed synthesis of an enantioenriched cyanohydrins. Highest enantiomeric ratio of $65: 35$ was achieved using benzaldehyde and pyruvonitrile in the presence of di-CF3-AcOLePPY catalyst at $10{ }^{\circ} \mathrm{C}$ in $1: 1 \mathrm{PhCF}_{3}: t-\mathrm{AmOH}$ solvent mixture. The mechanism of the cyanohydrin formation was elaborated to aid the development of more enantioselective synthesis of cyanohydrins.
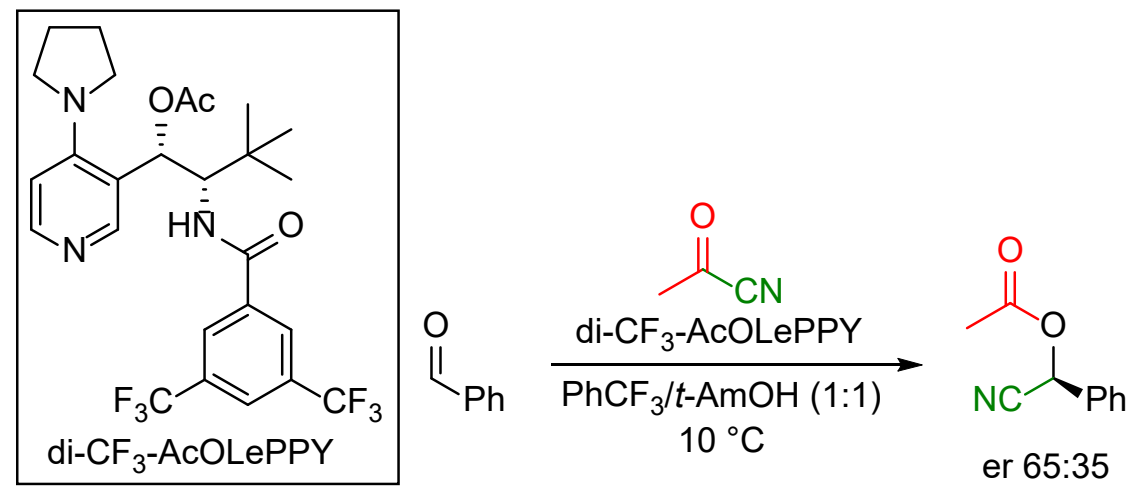

Supervisor: Dr. chem. Artis Kinēns

Acknowledgements: This work was supported by ERDF (Post-Doc Latvia) project No. 1.1.1.2/VIAA/3/19/589. 


\section{SYNTHESIS OF TETRAZOLO[1,5-C]QUINAZOLINE DERIVATIVES}

\section{Andris Jeminejs ${ }^{\star}$}

${ }^{1}$ Faculty of Materials Science and Applied Chemistry, Riga Technical University,

P. Valdena str. 3, Riga, LV-1048, Latvia

e-mail: andris.jeminejs@rtu.lv

Quinazoline core is a privileged molecular scaffold, which has already been proven as an effective tool in the treatment of different types of cancer. [1] Our group recently reported unorthodox arylsulfanyl group dance around quinazoline core, leading to novel 5(arylthio)tetrazolo[1,5-c]quinazolines 2. [2] This paves a path for the synthesis of modified compounds 3,4 and 5 that, otherwise requiring complex synthetic approaches, can be easily acquired with good to excellent yields from compound 2 .

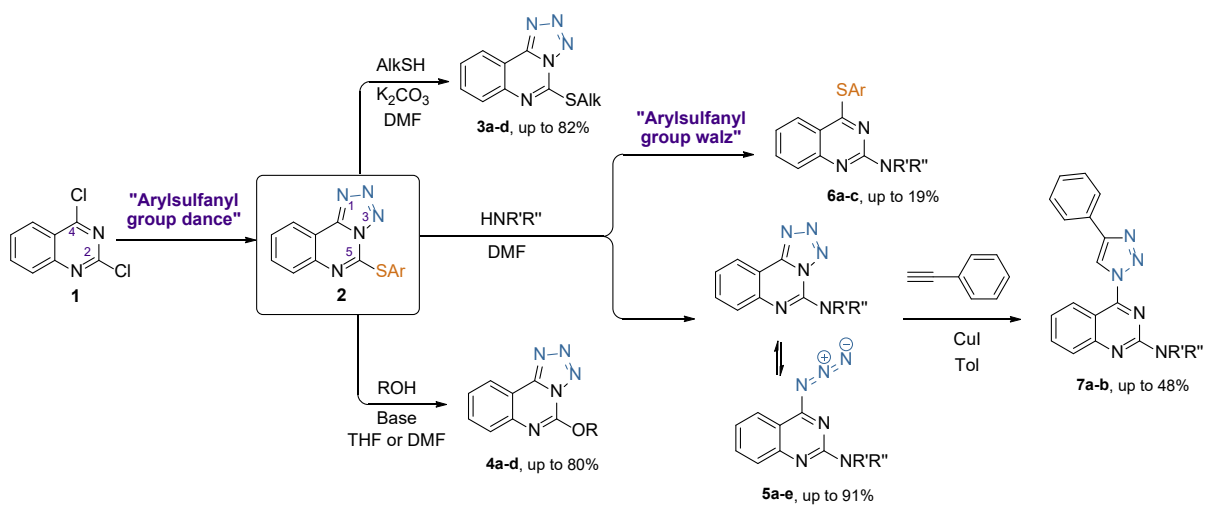

Most of these tetrazoloquinazoline derivatives exist mainly in their tetrazole tautomeric form both in a solid state and in solutions. However, some of the alkylamino derivatives $\mathbf{5}$ are observed to undergo azidoazomethine-tetrazole equilibrium that goes in line with general rules of temperature and solvent effects. [3] The presence of azide form can facilitate further modifications, for example, leading to novel fluorescent 4-triazolyl quinazoline derivatives 7.

This work was supported by the Latvian Council of Science grant No LZP-2020/1-0348.

Supervisors: Dr. chem. E. Bizdēna, Dr. chem. I. Novosjolova

\section{References:}

[1] Khan, I., Zaib, S., Batool, S., Abbas, N., Ashraf, Z., Iqbal, J., Saeed, A. Bioorg. Med. Chem. 2016, 24, 2361.

[2] Jeminejs, A., Goliškina, S. M., Novosjolova, I., Stepanovs, D., Bizdēna, Ë., Turks, M. Synthesis 2020, eFirst.

[3] Sirakanyan, S. N., Spinelli, D., Geronikaki, A., Kartsev, V. G., Panosyan, H. A., Ayvazyan, A. G., Tamazyan, R. A., Frenna, V. Tetrahedron 2016, 72(16), 1919-1927. 


\section{SYNTHETIC APPROACH TO SULPHUR BASED ENANTIOPURE $Y$-LACTAM BIOISOSTERES}

\section{Glebs Jersovs ${ }^{*}$}

${ }^{1}$ Latvian Institute of Organic Synthesis, Aizkraukles iela 21, Riga, LV-1006, Latvia e-mail:glersov@inbox.lv

Development of novel therapeutic agents presents a formidable multifaceted challenge prone to failure at different stages due to the unfavourable phisycochemical properties of lead compounds. The problem at hand can be alleviated via structural bioisosteric replacement targeted at the desired parameters. Importantly, successful implementation of this approach relies largely on the progress in domain of synthetic organic chemistry. Herein we propose to explore a synthetic route towards sulfur-based bioisosteres of $\gamma$-lactams, the scaffold ubiquitously present in bioactive molecules. A serendipitously discovered key cyclisation step leads to a versatile intermediate amenable to facile transformation into enantiopure sulfonamides, sulfonimidamides, sulfoximines and sulfonimidates.

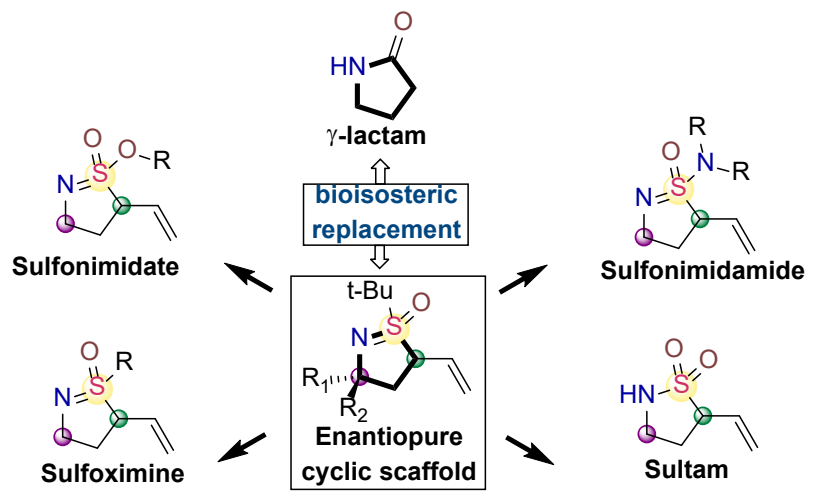

Supervisor: Prof., Dr. chem. E. Sūna 


\section{SYNTHESIS OF LINKERS FOR BIOCONJUGATION OF SARS-COV-2 RECEPTOR-BINDING DOMAIN SPIKE PROTEIN WITH Q $\beta$ VLPS}

\section{Sabīne Kaštaļjana*}

${ }^{1}$ Latvian Institute of Organic Synthesis, Aizkraukles iela 21, Riga, LV-1006, Latvia e-mail: sabine.kastaljana@osi.lv

Bioconjugation methods are used to link two molecules through a covalent bond, at least one of which is a biomolecule. Applications include creating antibody-drug conjugates for targeted drug delivery, attachment of fluorescent probes to biomolecules, crosslinking of proteins [1]. Bioconjugation is also used for vaccine development, triggering an immune response by attaching antigens to virus-like particles (VLPs) [2].

Reaction between tetrazine and a complementary strained dienophile, known as tetrazine ligation, is one of the fastest bioconjugation reactions known up to date. Reaction proceeds rapidly without catalysts via inverse electron demand Diels-Alder mechanism ( $i E D D A)$ and is irreversible due to the elimination of nitrogen gas. It is a great tool for conjugation of biomolecules as the fast rates allow conjugations at very low concentrations which minimizes the possibility of biomolecule degradation. Other advantages include mild reaction conditions, nontoxic byproducts and high selectivity [3].

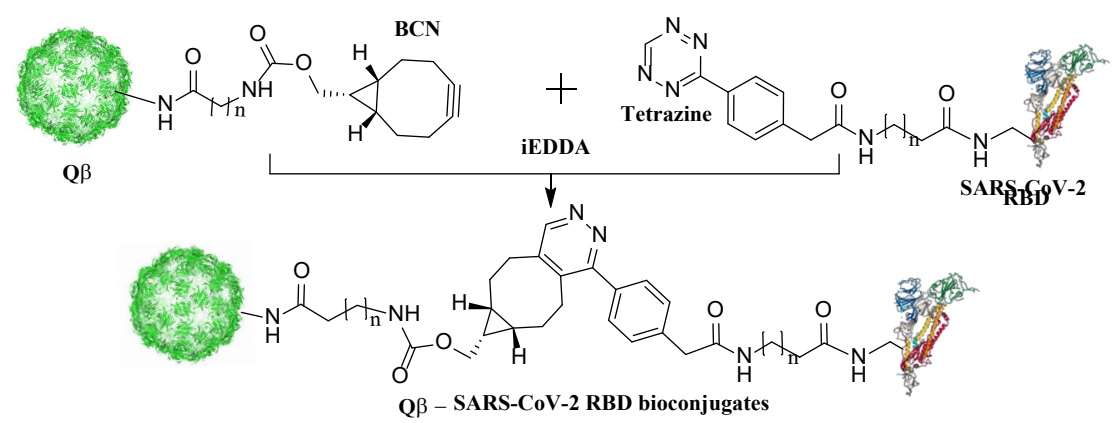

Herein we report synthesis of linkers containing tetrazine or bicyclo[6.1.0] non-4-yne (BCN) moieties, which were further used for chemical modification of SARS-CoV-2 RBD spike protein and Q $\beta$ VLPs. Modified RBD protein was linked with the chemically modified $\mathrm{Q} \beta$ VLPs employing iEDDA bioconjugation strategy. Bioconjugates were used in mice immunization and preliminary data indicates that the novel $\mathrm{Q} \beta-\mathrm{RBD}$ bioconjugation protocol could be used in a development of SARS-CoV-2 vaccine.

Supervisors: Prof., Dr. chem. E. Sūna, MSc. chem. R. Klüga

\section{References:}

[1] Hermanson, G. T. Bioconjugate Techniques, 3rd edition.; Academic Press: London, 2013, $1-125$.

[2] Akache, B.; Weeratna, R.; Deora, A.; Thorn, J.; Champion, B.; Merson, J.; Davis, H.; McCluskie, M. Vaccines 2016, 4, 3.

[3] Oliveira, B. L., Guo, Z., Bernardes, G. J. L. Chem. Soc. Rev., 2017, 46, 4895-4950. 


\section{SYNTHESIS OF NOVEL ASPARTIC-PROTEASE INHIBITORS FOR TREATMENT OF MALARIA}

\section{Vadims Kovada*}

${ }^{1}$ Latvian Institute of Organic Synthesis, Aizkraukles iela 1, Riga, Latvia

e-mail:vadim5555@inbox.lv

Malaria parasite has developed resistance to almost every known anti-malarial drug, so there is a growing need for new and effective drugs. Previously, it was demonstrated that compound $\mathbf{1}$ is potent inhibitor of haemoglobin-degrading enzymes (aspartic proteases, plasmepsins, Plm) with $\mathrm{IC}_{50}=60 \mathrm{nM}$ for PlmII and $\mathrm{EC}_{50}=0.3 \mathrm{nM}[1]$. In-vivo profiling of inhibitor 1 required large amounts of material, so a short, robust and inexpensive synthesis route that would be amenable to multi-gram scale synthesis was sought after.

The developed synthesis starts from the enantiopure derivative of glicerinaldehyde 2, and a new stereocenter was introduced by diastereoselective reaction $(\mathrm{dr}=95: 5)$, which allows us to obtain key building block 6 in $44 \%$ yield in 4 steps (instead of $6 \%$ in 6 steps in 1st generation scheme [2]) without usage of HPLC for separation of enantiomers. In addition, alternative synthetic route toward compound $\mathbf{1}$ was developed. The new route is shorter and provides higher yields of the target $\mathbf{1}$. Thus, inhibitor $\mathbf{1}$ was obtained in $10 \%$ yield over 8 steps, starting from compound $\mathbf{6}$. In contrast, the 1st generation scheme afforded $7 \%$ yield over 11 steps from 6 .

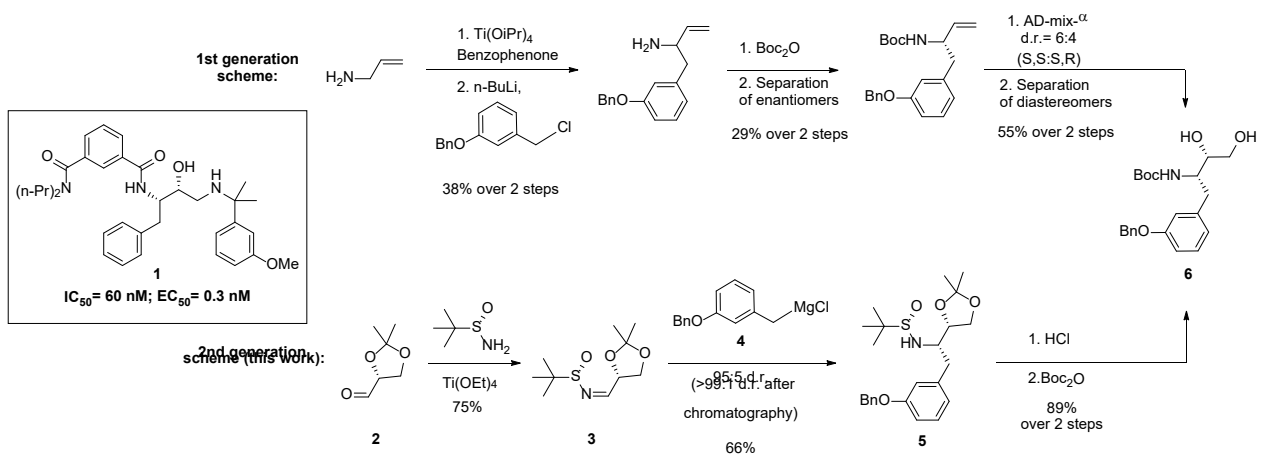

Supervisor: Dr. chem. E. Suna

\section{References:}

[1] Zogota, R.; Kinena, L.; Withers-Martinez, C.; Blackman, M. J.; Bobrovs, R.; Pantelejevs, T.; Kanepe-Lapsa, I.; Ozola, V.; Jaudzems, K.; Suna, E.; Jirgensons, A. Eur. J. Med. Chem. 2019, $163,344-352$.

[2] Kovada, V. Synthesis of novel aspartic-protease inhibitors for treatment of malaria. Těžu kräjums.: The 78th International Scientific Conference of the University of Latvia. Chemistry Section. Book of Abstracts. Rīga: Latvijas Universitāte, 2020, 50. lpp. 


\section{SYNTHESIS AND PHOTOPHYSICAL PROPERTIES OF STERICALLY HINDERED PURINE DERIVATIVES}

\section{Armands Sebris*}

${ }^{1}$ Faculty of Materials Science and Applied Chemistry, Riga Technical University,

P. Valdena str. 3, Riga, Latvia

e-mail: armands.sebris_1@rtu.lv

Fluorescence of purine derivatives has widely been studied for purposes of cell imaging [1], while application in materials science has only a few examples [2]. Earlier our group reported synthesis and photophysical properties of fluorescent purine push-pull systems with potential uses in cell imaging [3]. We have followed up this work with research in purine based thermally activated delayed fluorescence (TADF) emitters, which only recently has had a first published example [4].

In our initial attempts we synthesized compounds $\mathbf{1 , 2}$, which, according to DFT calculations, had separated HOMO and LUMO, and thus potential for TADF. These compounds had no emission in a solution, but moderate to good emission in a thin layer film and a crystalline phase. In our attempts to optimize the results achieved for compound $\mathbf{2}$ we introduced another electron donating group for compound $\mathbf{3}$ and also modified purine and carbazole moieties with different functional groups at circled positions of compound $\mathbf{2}$ to restrict intramolecular rotation that causes emission quenching.
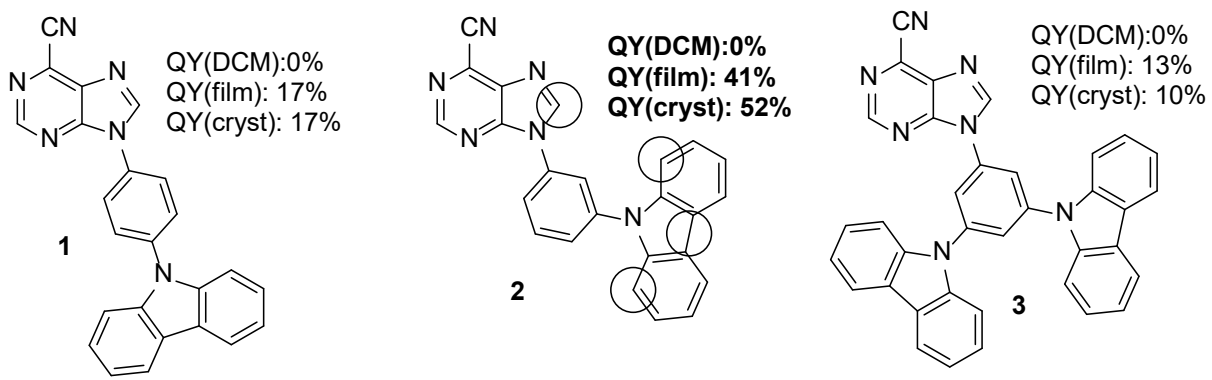

This work was supported by ERDF project Nr. 1.1.1.1/16/A/131. Dr. K. Traskovskis and Dr. A. Vembris are acknowledged for the photophysical measurements and calculations.

Supervisors: Dr. chem. M. Turks, Dr. chem. I. Novosjolova

\section{References:}

[1] Saito, Y.; Hudson, R. H. E. J. Photochem. Photobiol. C 2018, 36, 48.

[2] Yang, Y.; Cohn, P.; Eom, S.-H.; Abboud, K. A.; Castellano, R. K.; Xue, J. J. Mater. Chem. C 2013, $1,2867$.

[3] Šišuliins, A.; Bucevičius, J.; Tseng, Y.; Novosjolova, I.; Traskovskis, K.; Bizdēna, Ē.; Chang, H.; Tumkevičius, S.; Turks, M. Beilstein J. Org. Chem. 2019, 15, 474.

[4] Wang, Z.; Yao, J.; Zhan, L.; Gong, S.; Ma, D.; Yang, C. Dyes Pigm. 2020, 180, 108437. 


\section{SYNTHESIS AND PROPERTIES OF ISOELECTRONIC BRANCHED IONIC LIQUIDS}

\section{Diāna Sloboda*, Daniels Hazens, Igors Kḷimenkovs}

${ }^{1}$ Faculty of Chemistry, University of Latvia, Jelgavas iela 1, Riga, LV-1004, Latvia e-mail:diana.sloboda@lu.lv

Commonly used organic solvents make up a huge part of the waste from chemical industry. These solvents often are volatile organic compounds (VOCs) which can be harmful and dangerous, particullary when used on a large scale.

Ionic liquids (ILs) are low-melting salts that are liquid at ambient temperatures. Unlike VOCs, ILs are non-volatile and hard to ignite, therefore can be considered as safer substitutes for molecular solvents. IL solvent and physiochemical properties can be simply modified by changing IL cation or anion structure, enabling the solubilisation of diverse classes of solutes. This can also be of use in processes that involve gases, such as in chemical reactions or in separation of gas mixtures [1].

Since one of the factors promoting gas dissolution in ILs is the free volume within the liquid [2], ILs with voluminous branched side-chains are herein proposed as suitable candidates for processes involving gaseous solutes.

In this work, multi-gram preparation route of the highly branched imidazolium IL $\mathbf{1}$ and its silicon counterpart IL $\mathbf{2}$ was devised. Physiochemical properties of these novel materials were accurately determined and discussed in realtion to the well known linear alkyl-chain containing IL 3.
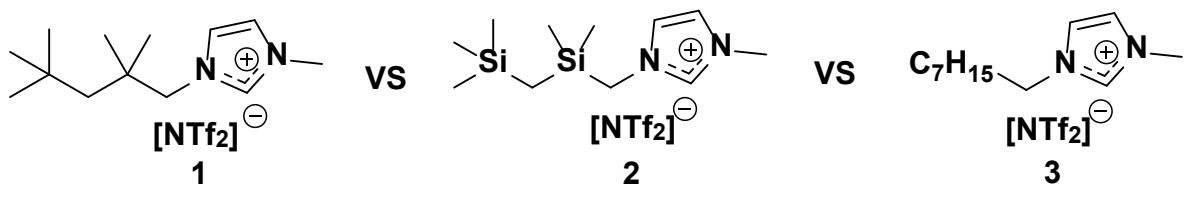

Supervisor: Dr. chem. E. Baķis

\section{References:}

[1] Moura, L.; Santini, C. C.; Costa Gomes, M. F.; Oil Gas Sci. Technol., 2016, 71.

[2] Liu, X.; O’Harra, K. E.; Bara, J. E.; Heath Turner, C., Phys.Chem. Chem. Phys., 2020, 22, 2061820633. 


\title{
SYNTHESIS OF FLUORINATED ISOXAZOLINE $N$-OXIDES THROUGH FLOUROMETHYLENE TRANSFER
}

\author{
Artūrs Sperga ${ }^{1,2^{*}}$ \\ ${ }^{1}$ Faculty of Materials Science and Applied Chemistry, Riga Technical University, \\ P. Valdena iela 3/7, Riga, Latvia \\ ${ }^{2}$ Latvian Institute of Organic Synthesis, Aizkraukles iela 21, Riga, Latvia \\ e-mail: arturs.sperga@inbox.lv
}

Fluorine containing compounds are extensively studied and applied in numerous areas such as materials, agrochemistry and medicinal chemistry [1]. Therefore, development of new synthetic methodologies for obtaining fluorinated molecules are of great interest.

Fluoromethylene transfer reactions are attractive approach for synthesis of 3-membered rings [2]. However, this strategy has not been employed for synthesis of five-membered rings. It is known that sulfonium salt $\mathbf{1}$ can function as a fluoromethylene transfer reagent [3]. Therefore, we envisioned that it could be used in formal [1+4] cyclization with $\alpha$-nitroacrylates 2 to obtain isoxazoline Noxides 3.<smiles>Cc1cc([Sb](CF)c2ccccc2)c(C)c(C)c1C</smiles>

1 (2 equiv)<smiles>[R]C=C(OCC)[N+](=O)[O-]</smiles>
$2^{\text {(1 equiv) }}$

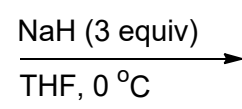

$$
\text { THF, } 0{ }^{\circ} \mathrm{C}
$$

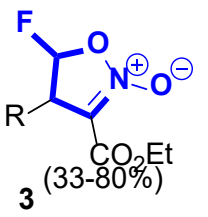

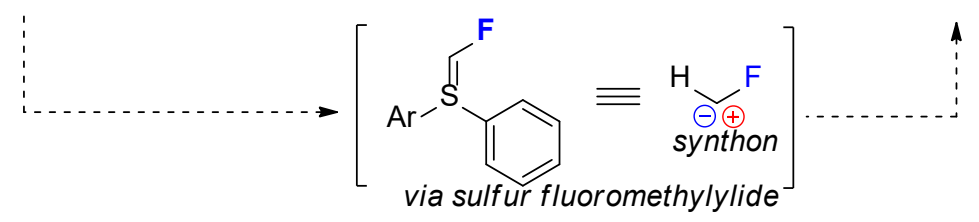

Herein we report that fluoromethylene transfer from sulfonium salts $\mathbf{1}$ is viable strategy for the construction of monofluorinated five membered rings 3 .

Supervisor: Dr. sci. nat. J. Veliks

\section{References:}

[1] Gouverneur, V.; Seppelt, K. Chem. Rev. 2015, 115, 563-565.

[2] (a) Decaens, J.; Couve-Bonnaire, S.; Charette, A. B.; Poisson, T.; Jubault, P. Chem. Eur. J. 2020, DOI: 10.1002/chem.202003822. (b) Veliks, J.; Kazia, A. Chem. Eur. J. 2019, 25, 3786-3789.

[3] Sperga, A.; Melngaile, R.; Kazia, A.; Belyakov, S.; Veliks J. J. Org. Chem 2021, DOI: 10.1021/ acs.joc.0c02561. 